\begin{abstract}
UNIVERSIDADE DE SÃO PAULO
FACULDADE DE FILOSOFIA, LETRAS E CIÊNCIAS HUMANAS DEPARTAMENTO DE LETRAS ORIENTAIS

PROGRAMA DE PÓS-GRADUAÇÃO EM LÍNGUA, LITERATURA E CULTURA JAPONESA
\end{abstract}

BRUNO TOMAZ CUSTÓDIO DOS REIS

MUSASHI, A TRAJETÓRIA DE FORMAÇÃO DE MIYAMOTO MUSASHI DURANTE O EXÍLIO

Versão corrigida

São Paulo

2018 


\section{MUSASHI, A TRAJETÓRIA DE FORMAÇÃO DE MIYAMOTO MUSASHI DURANTE O EXÍLIO}

Versão corrigida

Dissertação apresentada ao Programa de Pós-Graduação em Língua, Literatura e Cultura Japonesa do Departamento de Letras Orientais da Faculdade de Filosofia, Letras e Ciências Humanas da Universidade de São Paulo, para obtenção do título de Mestre em Letras, sob a orientação da Profa. Dra. Neide Hissae Nagae.

São Paulo 
Autorizo a reprodução e divulgação total ou parcial deste trabalho, por qualquer meio convencional ou eletrônico, para fins de estudo e pesquisa, desde que citada a fonte.

Catalogação na Publicação

Serviço de Biblioteca e Documentação

Faculdade de Filosofia, Letras e Ciências Humanas da Universidade de São Paulo Musashi, a trajetória de formação de Miyamoto Musashi durante o exílio / Bruno Tomaz Custódio dos Reis ; orientadora Neide Hissae Nagae. - São Paulo, 2018 .

$103 \mathrm{f}$.

Dissertação (Mestrado) - Faculdade de Filosofia, Letras e Ciências Humanas da Universidade de São Paulo. Departamento de Letras Orientais. Área de concentração: Língua, Literatura e Cultura Japonesa.

1. Literatura Japonesa. 2. Yoshikawa Eiji. 3. Musashi. 4. Exílio. 5. Romance de Formação. I. Nagae, Neide Hissae, orient. II. Título. 
REIS, B. T. C. MUSASHI, A TRAJETÓRIA DE FORMAÇÃo DE MIYAMOTO MUSASHI DURANTE O EXÍLIO. Dissertação apresentada

à Faculdade De Filosofia, Letras e Ciências Humanas da Universidade de São Paulo para a obtenção do título de Mestre em Letras.

Aprovado em:

Banca Examinadora

$\operatorname{Prof}(a) \cdot \operatorname{Dr}(a)$

Instituição:

Julgamento:

Assinatura

$\operatorname{Prof}(a) \cdot \operatorname{Dr}(a)$.

Instituição:

Julgamento:

Assinatura

$\operatorname{Prof}(a) . \operatorname{Dr}(a)$

Instituição:

Julgamento:

Assinatura 


\section{AGRADECIMENTOS}

Muito especialmente agradeço à minha orientadora, Profa. Dra. Neide Hissae Nagae, por ter respeitado meus momentos, paciência, carinho e confiança no decorrer da pesquisa.

Aos meus pais, Luiz e Zélia, por todo o apoio em minha vida e formação. Dedico a eles todas minhas realizações, e sem eles, eu não seria nada.

Ao meu irmão, Felipe, mesmo com seu humor maluco, sempre me apoiou e vive me instigando a alçar voos mais longos.

À Carla Batista, pelo companheirismo maravilhoso, me estimulando nos momentos mais difíceis sem deixar de acreditar no meu potencial.

À Elena Wazima, por ter me ajudado tanto nesta etapa e em tempos passados. Tenho-a em meu coração como uma segunda mãe.

Ao Prof. Dr. Marcio Roberto Pereira da UNESP/Assis, por ensinar e incentivar os primeiros passos na pesquisa científica.

Ao Vinícius Ito, amigo de graduação e pós-graduação, pelas conversas regadas de tanta besteira e dividindo as durezas da vida acadêmica.

À Julia Schaefer e Danilo Bertoni, pelas extraordinárias contribuições.

À CAPES pela bolsa concedida que me permitiu dedicar integralmente à pesquisa. 
"Nunca me senti só. Gosto de estar comigo mesmo. Sou a melhor forma de entretenimento que posso encontrar."

(Charles Bukowski) 


\section{RESUMO}

Musashi (1935-1939), romance de Yoshikawa Eiji serializado pelo jornal Asahi Shimbun e considerado por John Scott Miller (2009) como um romance de formação, narra desde o retorno de Miyamoto Musashi da Batalha de Sekigahara (1600) até a vitória contra Sasaki Kojirō na ilha de Ganryū (1612), quando torna-se um dos maiores espadachins da época. Um Japão que sofria uma grande transição na entrada do século XVII é o palco para a formação de Musashi frente ao mundo japonês e aos próprios sentimentos e escolhas. Todas essas mudanças estão entrelaçadas na decisão do autoexílio após a reclusão em meio ao alcance da erudição, visto que anteriormente a este divisor de águas, o próprio protagonista sentiu-se incompreendido e excluído por familiares e demais membros da sociedade. Para desenvolver esse estudo, fizemos alguns recortes da trajetória de Musashi para entendermos a essência de seu isolamento, e sua opção por preservar sua individualidade de modo que the possibilitasse exercer a sua criatividade. Desta forma, com base no panorama sobre o Bildgunsroman (Romance de Formação) feito por Wilma Maas (2000), poderemos acompanhar os estímulos e aspirações que o movem rumo à sua formação, até atingir um desenvolvimento totalmente único. E para compreendermos as motivações que fizeram Musashi a adotar o exílio como estilo de vida, além de atestar os seus ganhos, fundamentamos nos estudos de Katō Shūichi (2012) e Edward Said (2003).

Palavras-chave: Musashi; Yoshikawa Eiji; Literatura Japonesa; Exílio; Bildgunsroman; Romance de Formação. 


\begin{abstract}
Musashi (1935-1939), Yoshikawa Eiji's novel serialized by the newspaper Asahi Shinbun and considered by John Scott Miller (2009) as a Bildungsroman, it narrates from Miyamoto Musashi's return from the battle of Sekigahara (1600) to his victory against Sasaki Kojirō in Ganryū island (1612), when he becomes of the best swordsmen at that age. The early seventeenth century Japan that underwent a major transition is the stage for the formation of Musashi in light of the Japanese world and his own feelings and choices. All these changes are intertwined in the decision of self-exile after the seclusion amid the range of erudition, as previously to this watershed, the protagonist himself felt misunderstood and excluded by his family members and the other members of society. In order to develop this study, we will make a clipping of Musashi's path to understand the essence of his isolation, and his choice to preserve his individuality so that it makes it allowed him to exercise his creativity. Thus, based on the panorama on the Bildgunsroman (Romance of Formation) made by Wilma Maas (2000), we will be able to follow the stimuli and aspirations that guides him toward his formation, until reaching a totally unique development. In order to understand $\mathrm{Mu}-$ sashi's motivation to adopt exile as a way of life, in addition to attesting his gains, we base on the studies of Katō Shūichi (2012) and Edward Said (2003).
\end{abstract}

Keywords: Musashi; Yoshikawa Eiji; Japanese Literature; Exile; Bildgunsroman; Romance of Formation. 
1. Foi adotado o sistema de transcrição Hepburn para os termos romanizados da língua japonesa, que aparecem nesta dissertação, bem como nomes próprio e cidades japonesas que nós brasileiros não temos tanto conhecimento, com exceção das citações que foram mantidas como nos seus respectivos originais.

2. Os nomes das pessoas obedecem à ordem em que são utilizados no Japão, com o nome precedido pelo sobrenome. 


\section{LISTA DE ILUSTRAÇÕES}

Figura 1 Musashi ao derrotar Shishido Baiken....................... 13

Figura 2 Retrato de Miyamoto Musashi, período inicial da era Edo (1603-1868) e autor desconhecido........................ 18

Figura 3 Episódio de Musashi no Asahi Shimbun....................... 19

Figura 4 Capas japoneses - editora Kodansha....................... 22

Figura 5 Capas brasileiras - editora Estação Liberdade................. 23

Figura $6 \quad$ Retrato de Yoshikawa Eiji................................. 25

Figura 7 Mapa do Japão por onde Musashi transitou no romance...... 30 


\section{LISTA DE TABELA}

Tabela 1 Personagens mais importantes da obra... 


\section{SUMÁRIO}

INTRODUÇÃO.

CAPÍTULO 1. MIYAMOTO MUSASHI, O ROMANCE MUSASHI E YOSHIKAWA EIJI.

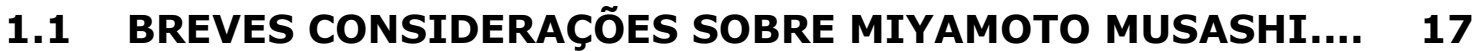

1.2 ASPECTOS GERAIS DO ROMANCE MUSASHI..................... 18

1.3 YOSHIKAWA EIJI, VIDA E OBRA................................... 24

1.4 SINOPSE DO ROMANCE............................................. 26

CAPÍTULO 2. O EXÍLIO DE MIYAMOTO MUSASHI, SUAS DIFICULDADES E TRIUNFOS.................................................. 31

2.1 AS PRIMEIRAS E CONTÍNUAS FERIDAS........................ 31

2.2 RECOMEÇO.................................................................. 41

2.3 FRÁGEIS RAÍZES........................................................ 46

2.4 O INÍCIO DE UM NOVO ÓDIO....................................... 49

2.5 O SURGIMENTO DO ANTAGONISTA ............................... 60

2.6 NOVO DISCÍPULO PARA UM NOVO MESTRE..................... 62

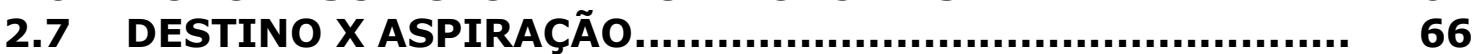

2.8 FINAL SEM FIM..................................................... 72

CAPÍTULO 3. OS CAMINHOS DE UMA FORMAÇÃO...................... 74

3.1 FORMAÇÃO COMO GÊNERO........................................... 74

3.2 MUSASHI COMO ROMANCE DE FORMAÇÃO......................... 76

3.3 PRIMEIROS PASSOS PARA A FORMAÇÃ́O.......................... 78

3.4 AS DIFICULDADE PARA UMA FORMAÇÃO GUERREIRA....... 83

3.5 FORMAÇÃO UNIVERSAL................................................. 85

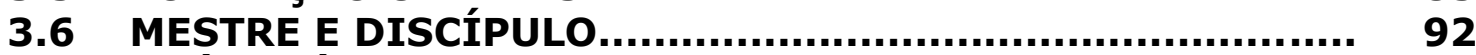

3.7 APÓS O ÚLTIMO EMBATE............................................... 95

CONSIDERAÇÕES FINAIS....................................................... 98

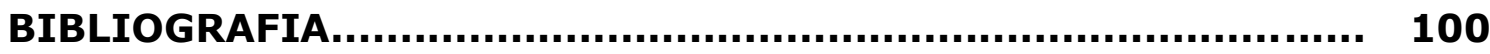




\section{INTRODUÇÃO}

O interesse em estudar o romance Musashi de Yoshikawa Eiji iniciou-se já no final da minha graduação, mas o embrião surgiu durante minha adolescência, quando fascinado pelos mangás e histórias de samurais, tive meu primeiro contato com o mangá Vagabond de Inoue Takehiko - baseado no romance citado acima. Esta obra, sem sombra de dúvida, até hoje, considero-a a mais sublime de todas. O que Takehiko colocou nas páginas de seu mangá me influenciou por um bom tempo.

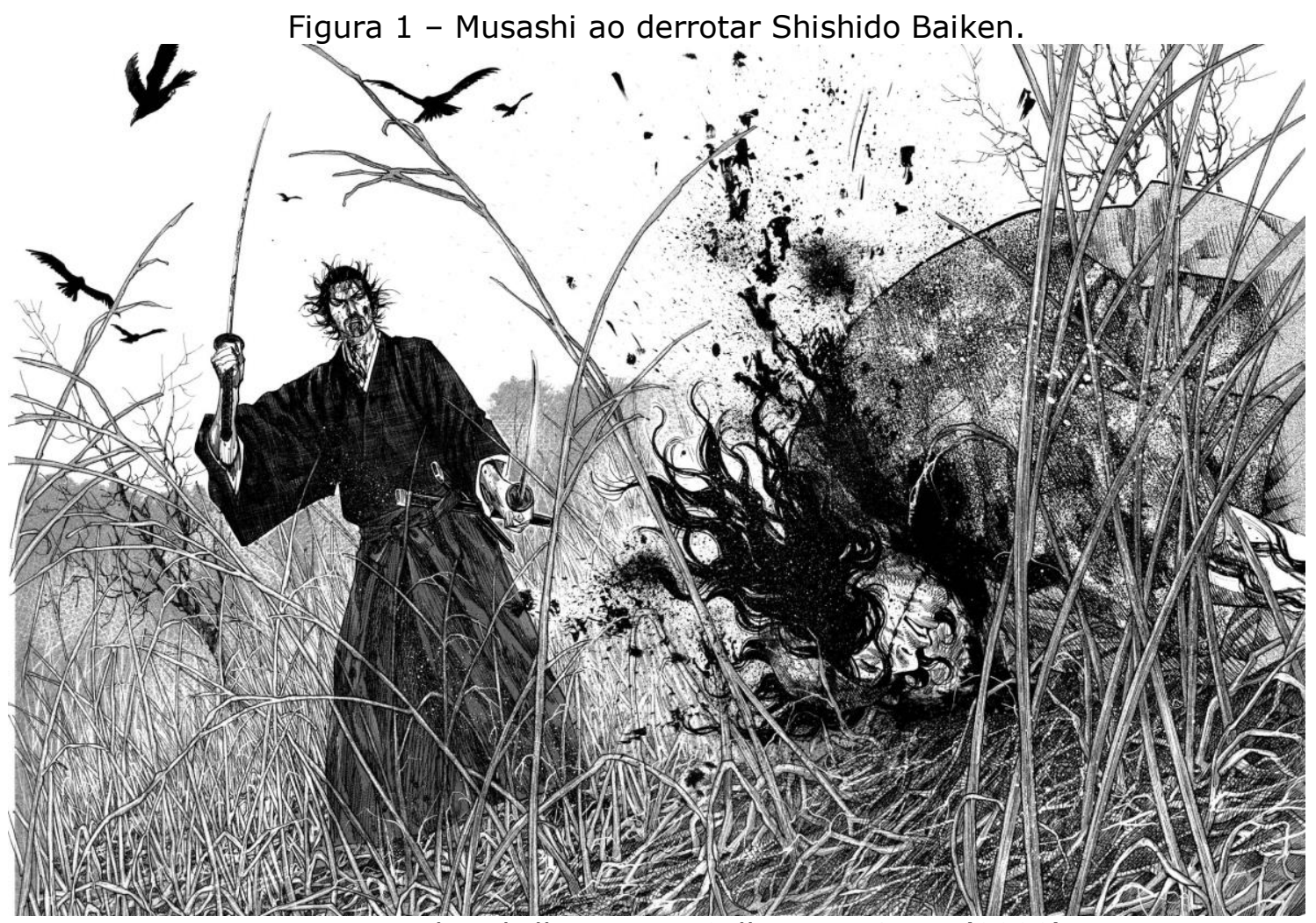

Fonte: Vagabond Illustration Collection: Sumi (2008)

Pouco tempo depois adquiri os dois volumes enormes escritos por Yoshikawa e resolvi embarcar nesta viagem de auto descobrimento do início do século XVII. Confesso que não foi fácil chegar até o final, há pouco mais de 10 anos. Pior ainda é ter de fechar esta obra ao fim do último capítulo. A cada releitura que fiz ao passar desses anos, sempre 
estive empolgado a cada episódio e até hoje descubro algo novo. Ler até hoje: "- Que lástima! O tigre retornou à selva!" (YOSHIKAWA, 2004, p. 1528) ainda me deixa muito alucinado, quase como um torcedor fanático.

Durante a graduação, tive a oportunidade de estudar mais a fundo sobre o exílio, mais especificamente em obras luso-africanas. Esta, para mim, de fato, é uma perspectiva que causa bastante estranheza. Porém, Musashi me chamava.

Começamos a observar o recorrente exílio que pairava no romance, exercido por outros personagens contra Musashi, fazendo com que este sempre fosse mantido à margem, aspecto característico do exílio. Além disso, Scott Miller (2009), no seu Historical dictionary of modern japanese literature and theater, cataloga o romance como um Bildgunsroman, uma vez que apresenta a trajetória de formação do personagem Miyamoto Musashi. Então, começaram a surgir indícios de que na obra Musashi as particularidades do exílio e da formação foram grandes transformadores na personalidade deste herói.

Assim, utilizando estes dois fundamentos, estabelecemos uma linha investigativa com o propósito de compreender como Musashi saiu de uma posição totalmente desfavorável, que o mantivera excluído, até tornar-se um famoso e exímio espadachim.

Antes de iniciarmos os estudos mais acadêmicos, teremos uma pequena apresentação de quem foi Miyamoto Musashi, personalidade real; um panorama da obra Musashi, com diversas informações sobre a estruturação do mesmo; uma exposição da vida e das obras do autor Yoshikawa Eiji; e por fim, uma sinopse do romance retirada do livro Yoshikawa Eiji - pessoa e literatura (OZAKI, 1980).

No primeiro capítulo, analisamos as motivações que levaram Musashi a submergir tão profundamente no exílio e como foi útil para o protagonista viver a vida desta maneira. Como fundamentação teórica utilizamos a teoria do exílio traçada e apresentada no livro Tempo e Es- 
paço na Cultura Japonesa (2012) de Katō Shūichi, por tratar das motivações que encadeiam um espírito de fuga de uma comunidade em um determinado indivíduo, variando a época e o lugar, com uma repressão enérgica pela liberdade individual exercida pelas regras da comunidade. Este controle excessivo tem o objetivo de preservar a segurança e a identidade do indivíduo, porém, existem regras impostas para que seja preservado o bom funcionamento de tal comunidade. Mesmo existindo o ato da fuga, não quer dizer que este venha a se configurar como exílio, pois há a necessidade de confiar num objetivo que transcenda os limites locais e cultivar o propósito de adquirir valores absolutos, independentemente do quão penoso será percorrer este caminho.

No livro Reflexões do exílio (2003) de Edward Said, somos levados a outra linha de pensamento em relação ao exílio, tendo em vista um lado mais árduo desta condição. Mesmo que haja exposições glorificando os triunfos alcançados, o desenvolvimento do indivíduo está estritamente ligado a uma ruptura entre o seu eu e sua terra natal. Desta forma, ao vivenciar o exílio, uma barreira do não-pertencimento constrói-se entre o indivíduo e o novo local, intensificando de forma abrupta a condição de marginalizado da sociedade. O exílio, por ser uma ação autônoma, parte do princípio de que o indivíduo já nasce nele, ou vem a acontecer em um determinado momento. Porém, para aqueles que conseguem lograr êxito nesta condição, primordialmente necessitam compreender que precisam extrair aprendizados que virão a facilitar a sua vida, mas não curar a ferida.

No segundo capítulo, atentaremos a esta viagem de aprendizado, isto é, como a relação do protagonista com os demais personagens foi moldando-o no decorrer do romance. A leitura da obra O Cânone Mínimo: O Bildungsroman na História da Literatura (2000) de Wilma Maas, auxiliou na compreensão do que podemos entender por romance de formação, resgatando-o cronologicamente desde a sua criação até o firmamento do termo. Com suas explanações, podemos perceber que o 
próprio termo sofre transformações ligadas à sua época e à cultura representada, não havendo necessariamente as mesmas características nas obras que relatam o desenvolvimento de um indivíduo.

No capítulo O romance de educação na história do realismo, no livro Estética da criação verbal (2011) de Mikhail Bakhtin, inicialmente discutem-se os heróis de imagens imutáveis e suas histórias com uma linearidade homogênea, mas o Bildungsroman surge como proposta de quebrar este indivíduo estático e concluso e dar espaço aos heróis com caracteres variáveis, acompanhando uma trajetória de desenvolvimento.

Para encerar, faremos algumas considerações finais que se afastam totalmente de uma conclusão, já que não chegamos nem perto de esgotar as possibilidades que o romance Musashi nos oferece. 


\section{CAPÍtUlo 1. MIYAMOTO MUSASHI, O ROMANCE MUSASHI E YOSHIKAWA EIJI}

\subsection{BREVES CONSIDERAÇÕES SOBRE MIYAMOTO MUSASHI}

Miyamoto Musashi 宮本武蔵 (1584-1645) é conhecido no Japão como um excêntrico espadachim, precursor de um novo estilo de esgrima, assim como pintor, escultor e calígrafo. Sua vida está envolta por mistérios e as fontes acerca da mesma são frequentemente contraditórias. Sabe-se que por alguns anos ele foi um shūgyōsha 修業者 - espadachim em treinamento que viajava pelo país e seguia o seu próprio caminho, estabelecendo neste aprendizado uma escola ou estilo -, assim como um kyūdōsha 求道者 - aquele que busca a verdade -, e durante este tempo veio a ter contato com diversos tipos de arte, além de pessoas de diversas classes sociais. Em boa parte da sua vida preferiu seguir como um andarilho e recusava com uma certa frequência convites de daimios ${ }^{1}$. Como resultado, em seu meio, tinha um considerável reconhecimento da sua arte e sem associar-se com algum estilo de combate já existente, criou de maneira autodidata o Niten ichi-ryū ニ天一 流 - o estilo Duas Espadas. As técnicas mais conhecidas deste estilo são as do manejo das espadas, mas sem se limitar apenas em técnicas com base nelas.

Para registrar seus ensinamentos marciais, Musashi escreveu três obras em vida. Estas eram: Hyōdōkyō 兵道鏡 ( $O$ espelho do caminho da guerra, 1604), que continha o esboço do Enmei-ryū 円明流 - conhecido como Perfeita Iluminação, Círculo do Brilho e Harmonia Final -; Hyōhō sanjūgo kajō 兵法 三十五䇢条 (Os 35 artigos das artes marciais, 1641), ampliação do livro anterior e próximo do livro posterior; e Gorin

\footnotetext{
${ }^{1}$ Daimyō 大名, título dado a todos os senhores que governavam grandes territórios e tinham grande número de vassalos.
} 
no Sho 五輪書 ( $O$ livro dos cinco anéis, 1645), suas explicações sobre o Niten ichi-ryū e sua superioridade frente a outros estilos.

Figura 2 - Retrato de Miyamoto Musashi, período inicial da era Edo e autor desconhecido.

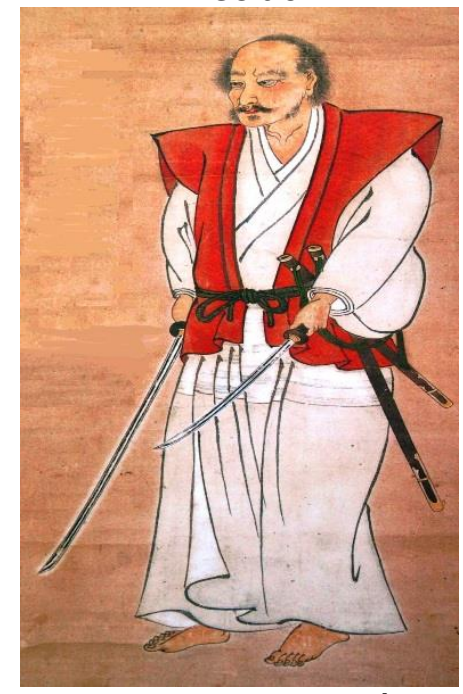

Fonte: Museu Shimada (Século XVII)

\subsection{ASPECTOS GERAIS DA OBRA DE YOSHIKAWA EIJI}

A obra homônima Musashi², escrita por Yoshikawa Eiji 吉川英治 (1892-1962), romanceia parte importante da vida desta personalidade. Foi publicada em forma de folhetim pelo Asahi Shimbun ${ }^{3}$ 朝日新聞 (Jornal Asahi) entre 1935 e 1939. O período entre as duas Grandes Guerras Mundiais, conforme Katō (1983, p. 247), ficou conhecido como era dourada dos romances populares no Japão, sendo o que a televisão era alguns anos atrás e o que a internet é hoje. No Brasil, sua publicação veio pela editora Estação Liberdade em 1998 com tradução de Leiko Gotoda ${ }^{4}$, sendo a primeira a trazer o texto integral no ocidente. Até 2008 , os números de exemplares vendidos já ultrapassavam os 100 mil livros,

\footnotetext{
${ }^{2}$ No Japão foi publicado como Miyamoto Musashi 宮本武蔵.

${ }^{3}$ Um dos cinco maiores jornais do Japão, fundado em 25 de janeiro de 1879.

${ }^{4}$ A tradutora Leiko Gotoda tinha interesse pessoal em apresentar elementos da cultura, história e artes marciais japonesas aos seus filhos, por acreditar que Musashi contemplava todos em uma única obra, sem que houvesse a necessidade de procurar todas essas informações em diversos livros historiográficos e culturais, além da possibilidade de estes não despertarem interesse nos jovens descendentes que estavam afastados diretamente, pela distância física, do país de seus antepassados.
} 
alavancados com a difusão do Niten ichi-ryū e a publicação do mangá (manga 漫画) Vagabond ${ }^{5}$ (Bagabondo バガボンド) escrito e ilustrado por Inoue Takehiko 井上雄彦, além de ressaltar o interesse dos brasileiros por temas que giram em torno da cultura japonesa.

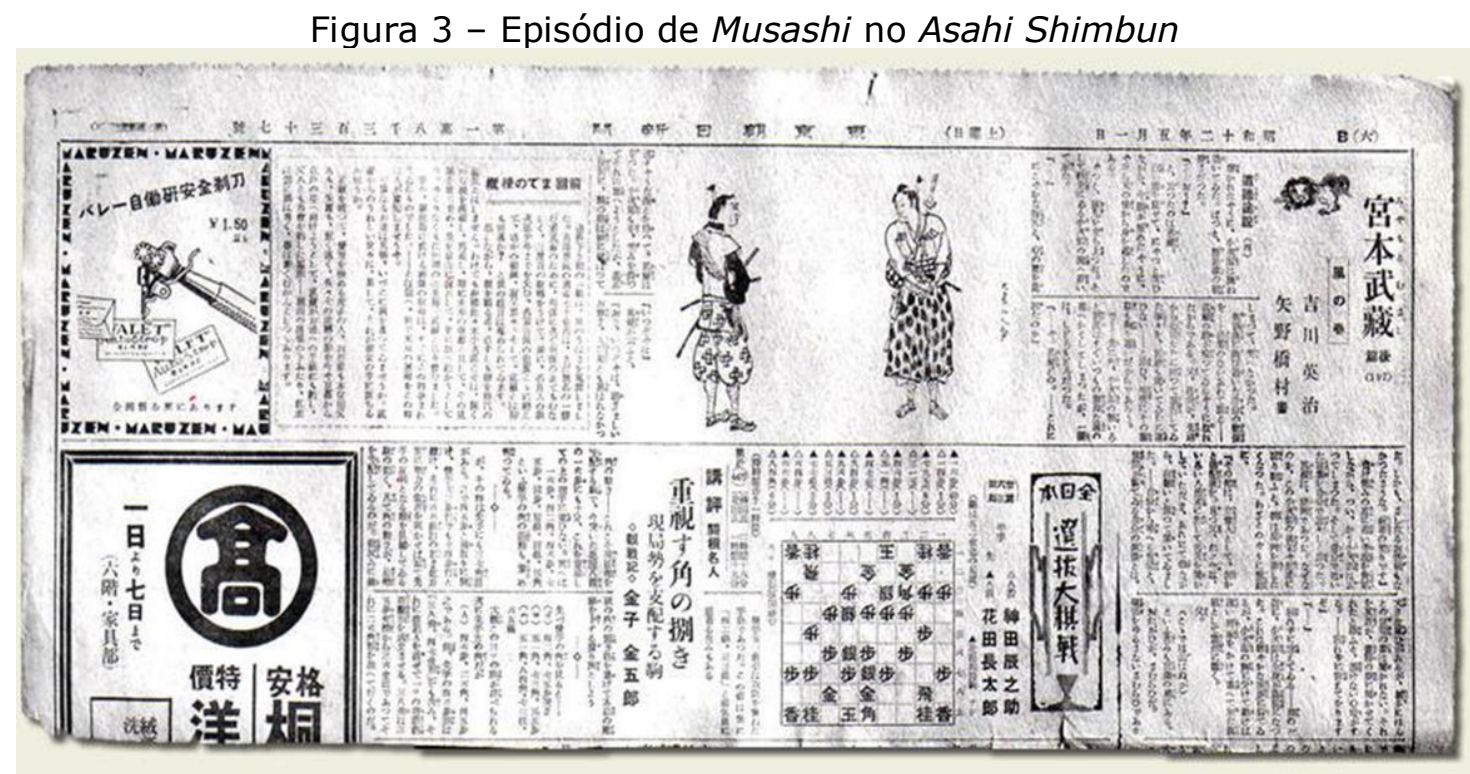

Fonte: Yahoo Japan Blogs (2008)

O romance retrata o desenvolvimento de Musashi como espadachim, suas interações com companheiros e inimigos, além dos conflitos que ele supera através da aprendizagem da importância da disciplina pessoal. O plano de fundo é um Japão em transição para o século XVI, apresentando diversas mudanças que afetariam o cotidiano japonês por quase 300 anos. A obra segue a trajetória cronológica com uma verossimilhança extraordinária, que Yoshikawa explora desde os aspectos pessoais até as questões históricas. São contemplados exatos 12 anos da vida de Musashi, cujo começo e fim são marcados pelo término de dois importantes acontecimentos. O primeiro é a batalha de Sekigahara (Sekigahara no tatakai 関ヶ原の戦い) e o segundo é o duelo contra Ganryū Sasaki Kojirō 祳流佐々木小次郎, os quais caracterizam o encerramento de ciclos representativos que dão início, em Musashi, a novas formas de refletir e decidir se o caminho tomado até então era compatível com a

\footnotetext{
${ }^{5}$ Começou a ser publicada em 1999, mas hoje segue em hiato.
} 
filosofia de vida adotada, e assim seguir novos rumos para o seu desenvolvimento. Segundo Wilson (2006, p. 218), o autor realizou uma grande pesquisa sobre a vida do herói, mas com a presença de diversas lacunas, foi necessário imaginar acontecimentos que pudessem preenchê-las.

Na obra Musashi, acompanhamos um contínuo deslocamento do protagonista por diversas regiões do Japão, desde a nova capital Edo 江 $\bar{F}^{6}$, com suas incessantes transformações, assim como Quioto, Osaka, Nara e Kokura ${ }^{7}$, conhecidas como cidades tradicionais. Uma das principais características em Musashi, que também podemos observar no romance, é que em sua trajetória os grandes centros não são predominantes, enquanto o interior ou regiões periféricas do país ganham certa notoriedade. Para o protagonista, o conhecimento pode ser encontrado ou alcançado em qualquer lugar, desde que o indivíduo esteja aberto a isto.

Para termos uma visão mais ampla sobre o tempo e o espaço da obra, além de podermos observar a progressão de Musashi, assim como a de outros personagens, Yoshikawa utiliza de um narrador heterodiegético. Desta forma, ainda que Miyamoto Musashi constitua-se como personagem principal da obra, a narrativa não se mantém presa exclusivamente ao mesmo, saltando também aos demais personagens e mostrando o desenvolvimento destes, pois todos compõem uma cadeia de relações com o protagonista.

Outro aspecto relevante é a quantidade de personagens que transitam pelo romance; são mais de 100. A vasta quantidade de personagens faz com que Musashi relacione-se com diversos tipos sociais, além de mostrar que seu caráter íntegro não era superficial, voltado apenas a receber ganhos daqueles que lhe interessavam.

\footnotetext{
${ }^{6}$ Passou a ser chamada de Tóquio (Tōkyō 東京) a partir do período Meiji (1868-1912).

7 Quioto (Kyōto 京都), Osaka (Ōsaka 大阪) e Nara (Nara 奈良) estão localizadas na região de Kansai 関西, no centro-sul da ilha de Honshū 本州; e Kokura 小倉 ao norte da ilha de Kyūshū 九州.
} 


\begin{tabular}{|c|c|}
\hline \multicolumn{2}{|r|}{ Personagens principais } \\
\hline $\begin{array}{l}\text { Hon'iden Matahachi } \\
\text { 本位田又八 }\end{array}$ & amigo de infância de Musashi \\
\hline $\begin{array}{l}\text { Hon'iden Osugi } \\
\text { 本位田お杉 }\end{array}$ & mãe de Matahachi e inimiga vingativa de Musashi \\
\hline $\begin{array}{l}\text { Otsū } \\
\text { おつう }\end{array}$ & ex-noiva de Matahachi e apaixonada por Musashi \\
\hline $\begin{array}{l}\text { Takuan Sōhō } \\
\text { 沢庵宗彭 }\end{array}$ & monge com uma postura excêntrica \\
\hline $\begin{array}{l}\text { Jōtarō } \\
\text { 城太郎 }\end{array}$ & seguidor e primeiro discípulo de Musashi \\
\hline $\begin{array}{l}\text { Sasaki Kojirō } \\
\text { 佐々木小次郎 }\end{array}$ & antagonista e adversário mais famoso da obra \\
\hline $\begin{array}{l}\text { Sannosuke Iori } \\
\text { 三之助伊織 }\end{array}$ & órfão e segundo discípulo \\
\hline \multicolumn{2}{|r|}{ Personagens secundários } \\
\hline $\begin{array}{l}\text { Okō } \\
\text { お甲 }\end{array}$ & uma mulher lasciva \\
\hline $\begin{array}{l}\text { Akemi } \\
\text { 朱美 }\end{array}$ & filha de Okō \\
\hline $\begin{array}{l}\text { Aoki Tanzaemon } \\
\text { 青木丹左 }\end{array}$ & pai de Jōtarō e oficial do governo Tokugawa \\
\hline $\begin{array}{l}\text { Fuchikawa Gonroku } \\
\text { 渊川权六 }\end{array}$ & irmão de Osugi \\
\hline $\begin{array}{l}\text { Ikeda Terumasa } \\
\text { 池田 輝政 } \\
\end{array}$ & senhor do castelo de Himeji \\
\hline $\begin{array}{l}\text { Hōzōin Inshun } \\
\text { 宝蔵院胤舜 }\end{array}$ & abade do templo Hōzōin \\
\hline $\begin{array}{l}\text { Yoshioka Seijurō } \\
\text { 吉岡清十郎 }\end{array}$ & jovem mestre do clã Yoshioka \\
\hline $\begin{array}{l}\text { Yoshioka Denshichirō } \\
\text { 吉岡伝七郎 }\end{array}$ & irmão mais novo de Seijurō \\
\hline $\begin{array}{l}\text { Gion Tōji } \\
\text { 祇園藤次 }\end{array}$ & samurai do clã Yoshioka e amante de Okō \\
\hline $\begin{array}{l}\text { Yagyū Sekishūsai } \\
\text { 柳生石舟斎 }\end{array}$ & antigo mestre do estilo Yagyū de esgrima \\
\hline $\begin{array}{l}\text { Hon'ami Kōetsu } \\
\text { 本阿弥光悦 }\end{array}$ & $\begin{array}{l}\text { famoso artista plástico e descendente de uma tradicional } \\
\text { família de polidores de espadas }\end{array}$ \\
\hline $\begin{array}{l}\text { Hon'ami Myōshū } \\
\text { 本阿弥妙秀 }\end{array}$ & carismática mãe de Kōetsu \\
\hline $\begin{array}{l}\text { Yoshino-dayū } \\
\text { 吉野太夫 }\end{array}$ & a primeira de uma série de cortesãs com o mesmo nome \\
\hline $\begin{array}{l}\text { Hosokawa Tadatoshi } \\
\text { 細川忠利 }\end{array}$ & $\begin{array}{l}\begin{array}{l}\text { suserano do clã Hosokawa com estreitos laços com o } \\
\text { xogunato }\end{array} \\
\end{array}$ \\
\hline $\begin{array}{c}\text { Nagaoka Sado } \\
\text { 長岡佐渡 }\end{array}$ & vassalo e secretário do clã Hosokawa \\
\hline $\begin{array}{l}\text { Musō Gonnosuke } \\
\text { 夢想権之助 }\end{array}$ & $\begin{array}{l}\text { exímio lutador com bastão que considera Musashi seu } \\
\text { mestre }\end{array}$ \\
\hline $\begin{array}{c}\text { Narai Daizō } \\
\text { 奈良井大蔵 } \\
\end{array}$ & falso mercante insurgente \\
\hline $\begin{array}{l}\text { Zushino Kōsuke } \\
\text { 厨子野耕介 }\end{array}$ & discípulo de Kōetsu e polidor de espadas \\
\hline
\end{tabular}


No Japão a obra publicada pela editora Kodansha 講談社 é dividida em oito volumes, enquanto no Brasil são dois ${ }^{8}$. Já no seu interior há sete livros: A Terra (Chi no maki 地の巻), A Água (Mizu no maki 水の巻), O Fogo (Hi no maki 火の巻), O Vento (Kaze no maki 風の巻), O Céu (Kū no maki 空の巻), As Duas Forças (Niten no maki 二天の巻) e A Harmonia Final (Enmei no maki 円明の巻), além de ter 166 capítulos e conforme Wilson (2006, p. 217), 1.013 episódios.

Figura 4 - Capas japoneses - editora Kodansha

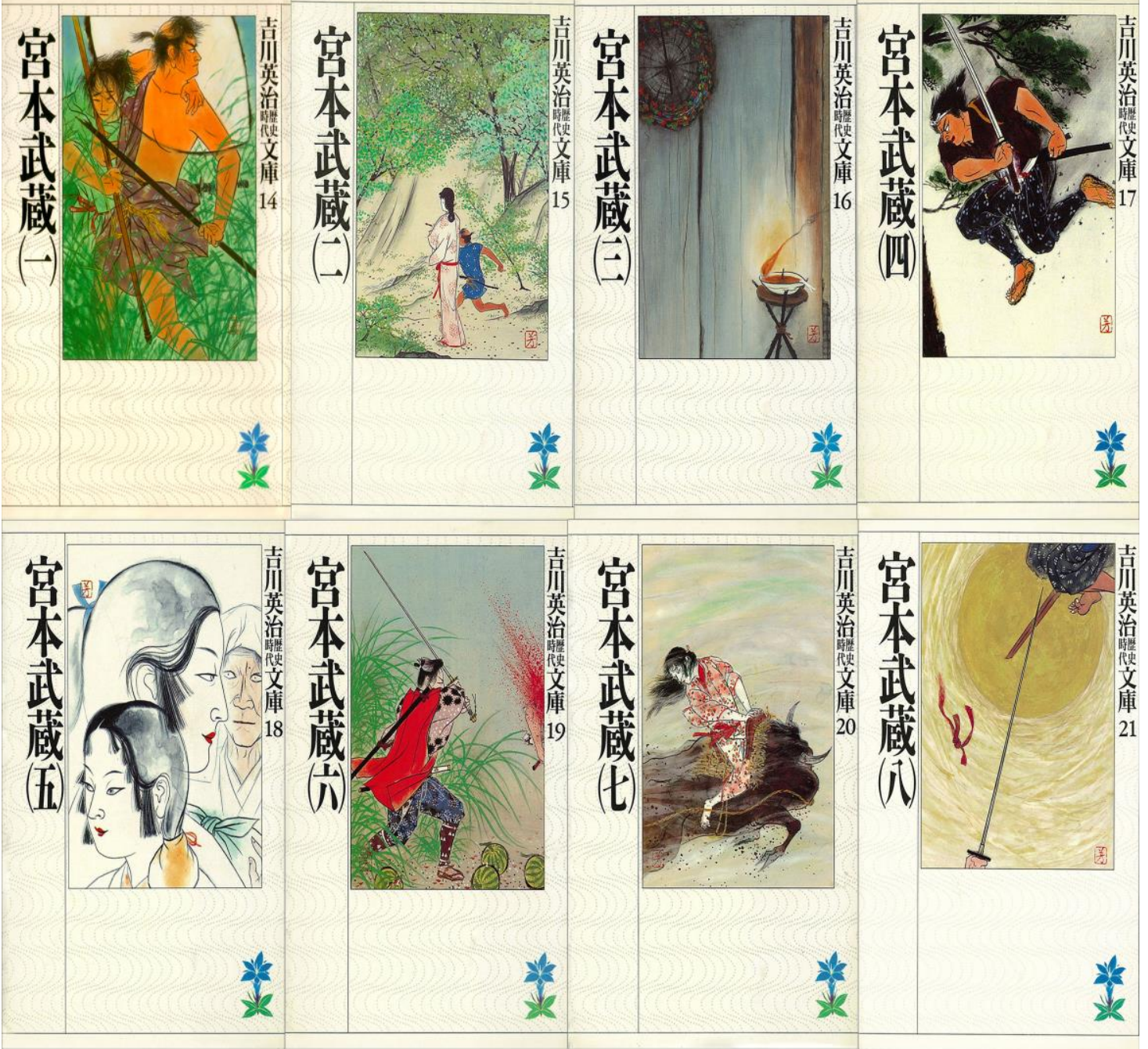

Fonte: Kodansha Book Club (s.d.)

${ }^{8}$ A divisão de volumes da obra é bastante variável, mas normalmente encontra-se nesta disposição. 
Figura 5 - Capas brasileiras - editora Estação Liberdade

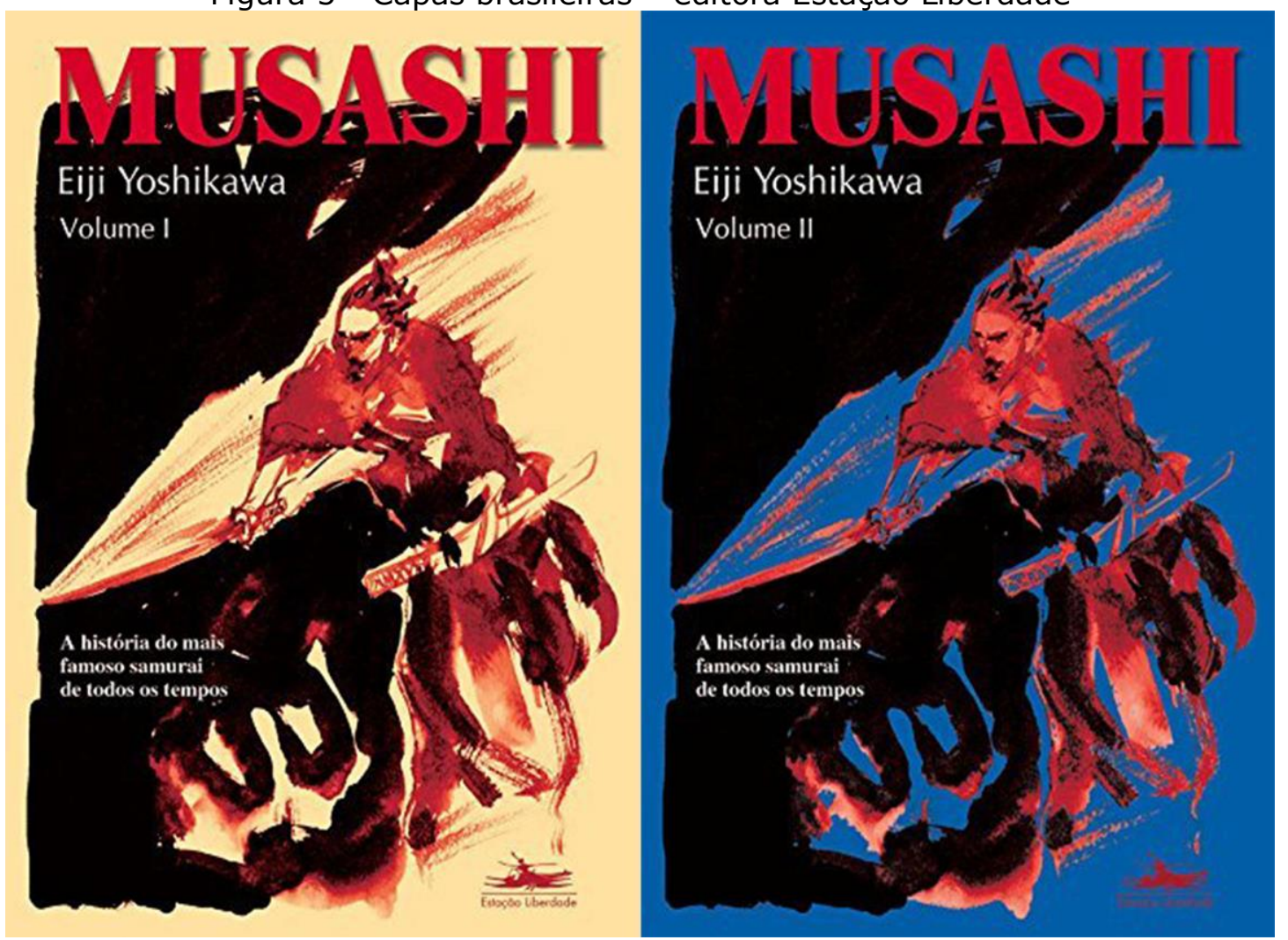

Fonte: Editora Estação Liberdade (s.d.)

Para que possamos compreender o romance e sua divisão, primeiro precisamos passar brevemente pelo livro Gorin no Sho, escrito por Musashi em seus últimos anos de vida. Considerado um tratado militar, seus escritos constituem-se de ensinamentos do seu estilo Niten ichi-ryū aos futuros discípulos, assim como uma exposição da superioridade de seu estilo em relação ao de outras academias. Esse livro é dividido em cinco capítulos - A Terra, A Água, O Fogo, O Vento e O Vazio -, uma referência ao pagode ${ }^{9}$ ou estupa de cinco andares, os quais representam estes mesmos cinco elementos. Essa construção, de acordo

\footnotetext{
9 "Esse gorinto é normalmente construído da seguinte maneira: uma pedra quadrada na base representa o elemento Terra, ou estabilidade e o elemento fundamental do ser; em seguida, uma pedra redonda representa o elemento Água, ou penetração e vácuo; uma pedra triangular representa o elemento Fogo, ou pureza e atividade perfeita; uma pedra com a forma de uma lua crescente representa o elemento Vento, ou crescimento e perfeita consciência; e, no alto, uma pedra na forma de uma jóia (gema que realiza desejos) representa o elemento Vácuo, ou espaço. As pedras são escritas respectivamente com as letras do sânscrito "A", "Vi", "Ra", "Hum" e Kham", que juntas representam o próprio Vairocana, a verdadeira essência do universo." (WILSON, 2006, p. 165-6, grifo do autor).
} 
com o budismo, guarda a presença real de Buda ou de sua Verdade, e a partir disto, Musashi propõe mostrar a sua verdade em relação às artes marciais, assim como a necessidade do indivíduo de perpetuar um posicionamento de características autônomas para que possa lograr no caminho percorrido.

Yoshikawa apropria-se destes cinco elementos e insere mais dois: Niten no maki e Enmei no maki - os quais, na edição brasileira, a sra. Gotoda preferiu traduzir como As Duas Forças e A Harmonia Final, respectivamente. Entretanto, nas edições americana, espanhola, francesa e italiana os livros são traduzidos como Sol e Lua e A Perfeita Luz. É possível supor que nas traduções a ideia foi tentar interpretar os acontecimentos destes livros. Por outro lado, Yoshikawa provavelmente tenha escolhido estes nomes para fazer uma referência clara aos estilos de combate de Musashi, Niten ichi-ryū e Enmei-ryū.

\subsection{YOSHIKAWA EIJI, VIDA E OBRA}

Yoshikawa Eiji foi um dos romancistas históricos preeminentes do Japão. Nascido em Yokohama, fora registrado como Yoshikawa Hidetsuku 吉川英次, adotando depois o prenome Eiji. Ele se juntou à sociedade poética de Tóquio na juventude e ganhou o prêmio do concurso de escritores romancistas patrocinados pela Editora Kōdansha com Enoshima Monogatari 江/島物語 (O Conto de Enoshima, 1914), passando a publicar diversas obras baseadas nos clássicos japoneses e chineses. Surpreende não só pela vasta quantidade de obras - aproximadamente 90 -, mas também pelo fato de algumas apresentarem uma longa duração da trama.

Enumeramos aqui um pequeno apanhado de suas obras: Shinran $k i$ 親鸞記 (Crônicas de Shinran, volume único, 1923), Kennan Jonan 剣難女 難 (Problemas com espadas, problemas com mulheres, volume único, 1926), Naruto Hichō 鳴門秘帖 (Textos secretos de Naruto, dois volumes, 
1927-1933)，Edo Sangoku shi 江戸三國志 (Os três reinos de Edo, três volumes, 1927-1929)，Yagyū Tsukikage shō 柳生月影抄 (Apanhados de textos de Yagyū Tsukikage, volume único, 1939), Sangoku shi 三国志 (Romance dos três reinos, 14 volumes, 1940-1946), Minamoto Yoritomo 源 頼朝 (obra homônima, dois volumes, 1940-1941), Shinsho Taikō ki 新書太 閣記 (Os novos escritos de Taiko, nove volumes, 1941-1945), Uesugi Kenshin 上杉謙信 (obra homônima, volume único, 1942), Kuroda Josui 黒 田如水 (obra homônima, volume único, 1943)，Ōoka Echizen 大岡越前 (obra homônima, volume único, 1950), Shin Heike monogatari 新平家物語 (Os novos contos dos Heike, 24 volumes, 1951-1957), Taira no Masakado 平 の将門 (obra homônima, volume único, 1952)，Wasurenokori no ki 忘れ残り の記 (Fragmentos do passado, volume único, 1957), Shihon Taihei ki 私本 太平記 (Registros privados das crônicas da grande paz, 13 volumes, 1959-1962), Shin Suikoden 新水湤伝 (Novas histórias da margem da água, seis volumes, 1960-1963). A maioria dos seus trabalhos é composta por releituras de obras clássicas, mas também uma leitura da vida de algumas personalidades, assim como vemos em Musashi.

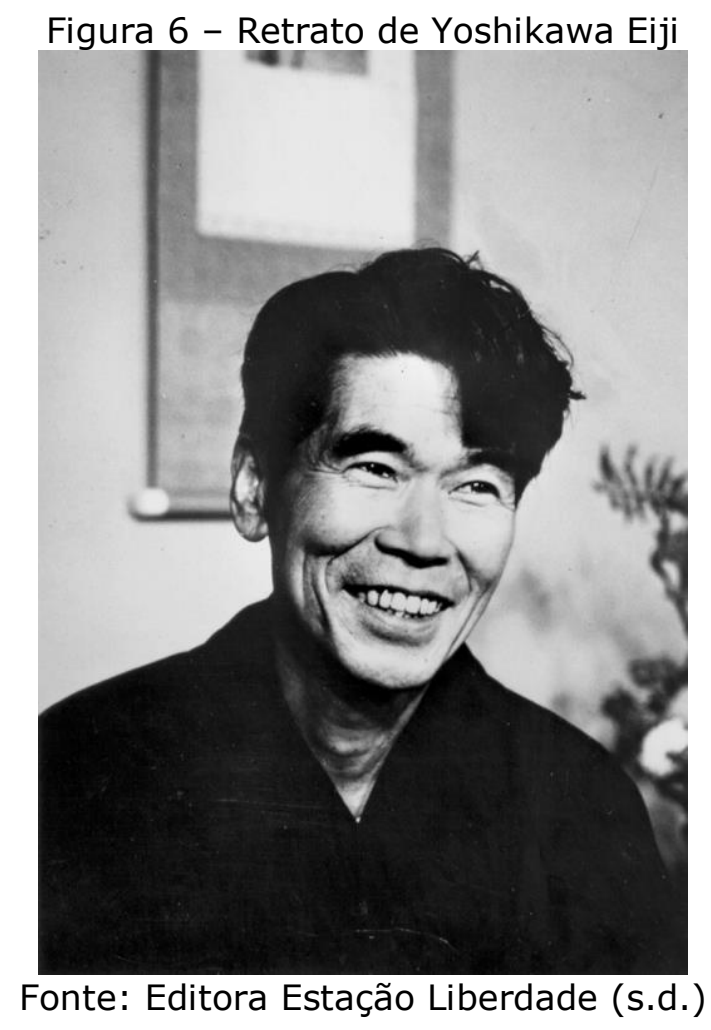


Parte de sua produção foi lançada na revista Kingu キング10 (King, 1925-1957), sendo ele um dos principais contribuidores. Nesta revista, segundo Yamagiwa (1959, p. 10), um grupo de histórias de aventura era estabelecido no passado, o qual retratava seus famosos heróis com seus grandiosos duelos de espadas. Estes tinham uma qualidade sem igual de se aproximarem das situações das massas. Para os jovens da época, o modo de vida de Miyamoto Musashi como aquele que está em busca de algo era um exemplo a ser seguido. Com base em uma pesquisa de grupo sobre cultura popular liderada por Kuwahara Takeo, publicada em 1964 com o título de "Miyamoto Musashi" e os japoneses, Ozaki (1980, p. 37) explica que essa visão que existia durante a guerra se manteve no pós-guerra e que a obra possui elementos que tocam o sentimento do povo pela sua estrutura de pensamento, que são: espírito de busca, amor entre parentes de sangue e sentimento de compaixão, pensamentos estes basilares da camada popular e que coincidem com os de Yoshikawa Eiji.

Yoshikawa veio a falecer de câncer em 1962. Quatro prêmios foram nomeados em sua homenagem: Prêmio Yoshikawa Eiji de Literatura 吉川英治文学賞 (1967)，Prêmio Yoshikawa Eiji de Cultura 吉川英治文化賞 (1967), Prêmio Yoshikawa Eiji para Novos Escritores 吉川英治文学新人賞 (1980) e Prêmio Yoshikawa Eiji de Séries Literárias 吉川英治文庫賞 (2016).

\subsection{SINOPSE DO ROMANCE}

Antes de iniciarmos a análise, traduzimos a sinopse do romance, escrita por Mitsutake Toshirō - membro da Associação de Pesquisa de Literatura Popular -, que compõe o livro Yoshikawa Eiji - pessoa e literatura, de Ozaki Hideki (1980, p. 304-5):

\footnotetext{
${ }^{10}$ Conforme Yamagiwa (1959, p. 68), a revista Kingu tinha como objetivo tornar-se uma revista para toda a nação, independentemente da idade, sexo e classe social, a fim de atingir cada família de todo o país. Introduziu muita novidade e vivas narrativas da cena social e política, além de pedaços emocionantes de ficção.
} 
Miyamoto Musashi, aos 17 anos, ainda sob o nome de Takezō, sai para a batalha de Sekigahara com uma lança juntamente com Matahachi, seu amigo de infância. Takezō, que saiu com vida na derrota que ceifou a vida de 9 entre 10 guerreiros, separa-se de Matahachi, que se envolveu com uma mulher enquanto retornavam para sua aldeia, e segue rumo à aldeia Miyamoto em Sakushū (outro nome da Província de Misaka). No trajeto, quebra a barreira de inspeção na fronteira e passa a ser perseguido pelo clã Himeji. Devido a essa "falta de conhecimento de mundo de Takezō", mencionada pelo monge Takuan, o destino dele muda muito. No capítulo "O diálogo da árvore e da pedra" ocorre uma discussão com o monge e Takezō começa a enxergar melhor as coisas. $E$, ao ser-lhe dito para "pensar na cela escura como o útero materno e se preparar para o nascimento", ele passa três anos preso na sala fechada do Castelo das Garças Brancas. O local transforma-se em espaço para seu próprio aprimoramento. Ele lê milhares de livros e quando retorna ao mundo, está com 21 anos. Foi quando mudou o nome para Miyamoto Musashi.

Ele, que não pensava nas pessoas como gente, nesse ínterim renasceu como um ser humano capaz de sentir gratidão pelo outro. No entanto, pelo fato de ter vencido o $d \bar{o} j \bar{o}^{11}$ 道場 Yoshioka e enquanto percorreu os $d \bar{o} j o \bar{o}$ de famosos estrategistas, ele correu o risco de dar crédito demais à sua habilidade. Controlando com rigor esse sentimento, ele, que dizia ser um espadachim solitário, passa a pensar no que é preciso fazer para se tornar o espadachim invencível de todo o reino, e alcança o estado de entender que o treinamento do verdadeiro guerreiro bushi não consiste apenas na técnica guerreira, mas necessita de exercício espiritual. Os encontros com o monge Takuan, Nikkan do templo Ozo, Yagyū Sekishūsai, com mãe e filho Kōetsu, com o velho mestre ceramista que vive num canto da cidade, e as atitudes e palavras dos mes-

\footnotetext{
${ }^{11}$ Literalmente, "lugar do caminho". Salão de treinamento para artes marciais.
} 
mos indicaram vários nortes a ele, que só buscava o caminho do espadachim.

Por outro lado, temos Otsū, a mulher "fria e solitária como as cinzas de um incensário", que segue e admira Musashi; e a menina Akemi que se preocupa com Musashi e que "tem um suspiro quente como o calor da erva primaveril". Também há o menino Jōtarō, Hon'iden Matahachi, a velha Osugi, mãe de Matahachi. Atrelada às ações de Sasaki Kojirō, que parece relapso, mas também sabe de etiquetas, a história desenvolve-se com vagas que vão e vêm.

Na batalha do Pinheiro do templo Ichijō, Musashi vence a família Yoshioka e, pelo sentimento de responsabilidade demasiada pelo menino Genjirō, (a grande esperança do clã Yoshioka), o grande lutador do Yoshioka Dōjō, que é vencido com um único golpe, chega a pensar em quebrar a espada. Mas ele mantém a determinação de "não se arrepender diante dos fatos". Esculpe uma imagem de Avalokitesvara; muito mais para dar continuidade à sua ação sábia para com a vergonha e o arrependimento de seu próprio espírito do que para sufragar o garoto, ele se conscientiza da "pequenez do seu ser que vive sob o imenso universo".

Mais tarde, Musashi, em uma aldeia da Província de Shimousa, torna o menino Iori seu discípulo, deixa a espada por um tempo e se dedica ao uso da enxada, pensando em "não apenas escalar a perfeição humana de si mesmo com a espada, mas dar o exemplo de governar o país assegurando a tranquilidade dos aldeões". Faz com que os aldeões peguem em armas e, com a união, obtém sucesso em derrotar o administrador daquelas terras. Aproxima-se, ainda, do zen-budismo, conhecendo o princípio do estilo das duas espadas por meio do tambor kagura do santuário; a partir do círculo desenhado pelo Mestre Zen Gudō, "entende que ele próprio é um círculo, o céu e a terra são um círculo, e não podem ser a mesma coisa", aproximando, assim, passo a passo do caminho de seu aperfeiçoamento. Em seguida, na ilha Funajima, acontece 
a batalha com seu inimigo Sasaki Kojirō. Nessa disputa, Musashi derrota Kojirō, ao contrário do que as pessoas esperavam, mas ele sente amor e respeito pelo oponente, que perde um olho quando corta a faixa da cabeça.

Esse romance, que narra a história do garoto bagunceiro que era um estorvo para os aldeões, busca um caminho de vida, e por meio do aprimoramento pela espada, alcança o estado de unidade espada-zen, transforma totalmente a visão que se tinha de Musashi; trata-se de uma obra-prima que cria a imagem humana de um ser em busca do caminho da espada, e demonstrou um pico a que chegou a literatura popular. O autor compara as espadas de Sasaki Kojirō e de Musashi e diz: "Kojirō acreditava na espada enquanto técnica e força e Musashi, na espada da mente. Essa era a única diferença". Escreveu também sobre Musashi como "Uma pessoa que vislumbrou e tolice e a sabedoria humana por meio da espada e que, até morrer, sofreu se perguntando como lidar com o instinto de sobrevivência pela luta do ser humano que é um poço de desejos impuros". A consciência do jovem Takezō reflete a visão de vida do próprio autor. Numa época tensa em que começava a guerra sino-japonesa, o modo de vida de Musashi foi muito lido e apreciado como um importante ensinamento de vida.

O livro Miyamoto Musashi e os japoneses, organizado pelo Grupo de Pesquisas da cultura popular centralizado em Kuwahara Takeo, aponta que após a Segunda Guerra Mundial, a consciência de busca, o amor pelos parentes de sangue e o sentimento de compaixão despontaram, e é possível dizer que se trata de uma obra clássica com esses elementos que angariam a simpatia básica dos japoneses. Desde a sua publicação foram feitos filmes, peças de teatro novo e também kyōgen com base nela. 
Figura 7 - Mapa do Japão por onde Musashi transitou no romance
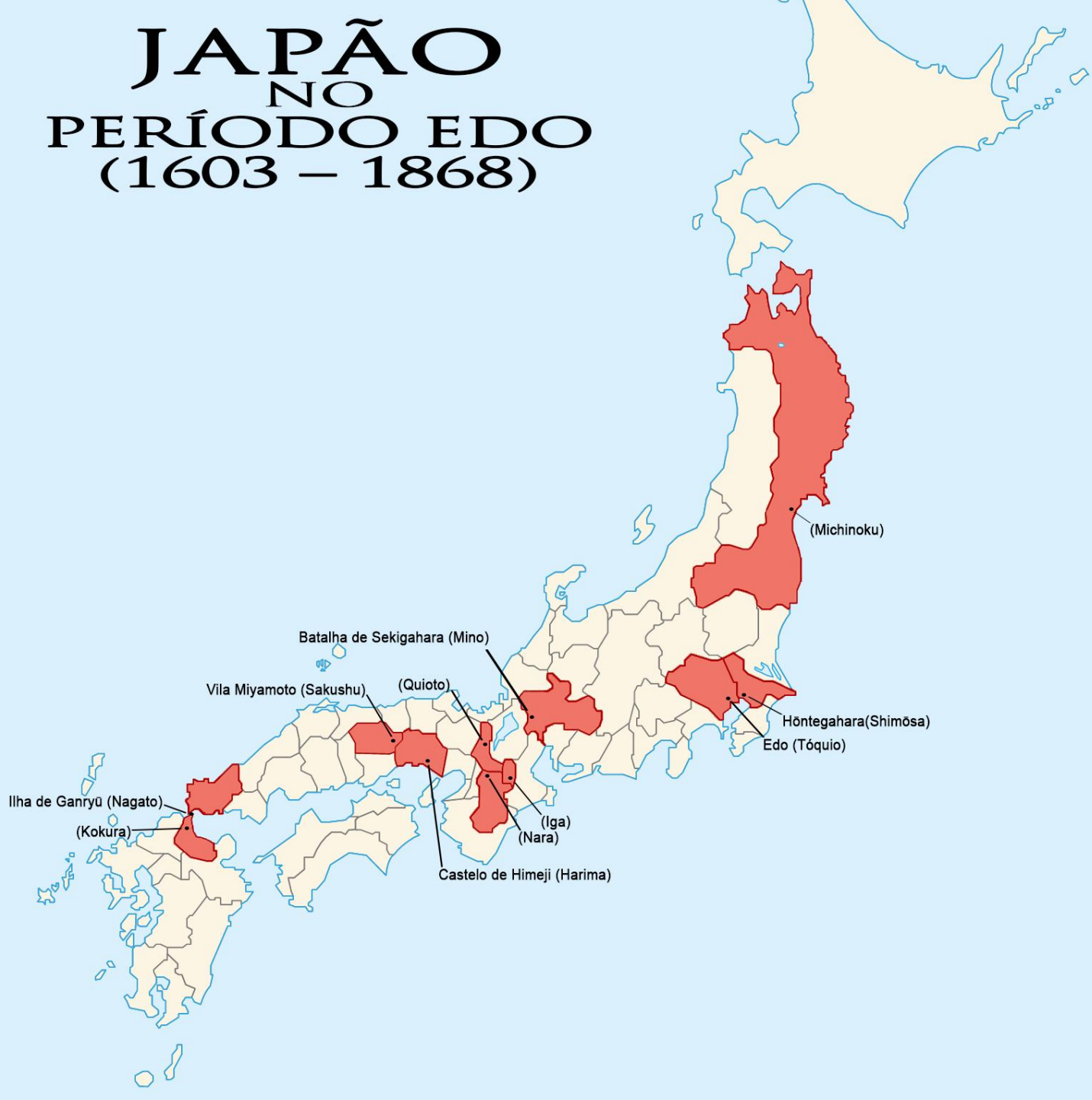

Fonte: elaborado pelo autor 


\section{CAPÍtULO 2. O EXÍlIO DE MIYAMOTO MUSASHI, SUAS DIFICULDADES E TRIUNFOS}

"O exílio nos compele estranhamente a pensar sobre ele, mas é terrível de experienciar." (SAID, 2003, p. 46)

\subsection{AS PRIMEIRAS E CONTÍNUAS FERIDAS}

A análise, por uma perspectiva de contínuo exílio, de toda a trajetória de Miyamoto Musashi, romanceada por Yoshikawa Eiji, faz com que nós, leitores, adotemos uma postura mais atenciosa ao refletirmos sobre os acontecimentos não como meras eventualidades. Como poderemos observar, em diferentes esferas da sociedade haverá sucessões de exílio direcionados ao protagonista por ele não ser um indivíduo compatível com os preceitos que regem o mundo japonês do século XVII.

O exílio de um sujeito ou grupo leva à prática da exclusão e/ou banimento - assim como suas variáveis: um afastamento imposto ou voluntário, repulsa, marginalizar, afastamento total do convívio social etc. - e este que o sofre, não sendo possível permanecer em sua terra natal, necessita procurar refúgio em um mundo, às vezes, totalmente desconhecido. Mas para que isto realmente venha a ocorrer, há a necessidade de surgir e sustentar um estigma entre quem sofre e aqueles que excluem, ao ponto de tornar-se insuportável a vida em comunhão. Para que possamos compreender as motivações, os atos e suas reações, utilizaremos como base inicial as reflexões apresentadas por Katō Shuichi e Edward Said, onde um discorre especialmente sobre esta condição num Japão feudal, e o outro sobre questão do desenvolvimento do exilado em um novo território.

Na composição do romance Musashi temos a formação do protagonista inicialmente como um indivíduo comum e sem muitas qualida- 
des, até chegar a um dado prestígio apresentado em diversas esferas da sociedade. Mesmo que Musashi tentasse evitar, as relações sociais foram imprescindíveis para que seu desenvolvimento como indivíduo ocorresse. Entretanto, é a partir das relações interpessoais que as primeiras feridas surgiram no íntimo do protagonista; incompreendido por seu pai e conterrâneos da vila, o jovem Shinmen Takezō ${ }^{12}$ fora um indivíduo diferente daqueles que o cercavam, e quanto mais era repreendido, mais crescia-Ihe um instinto de revolta.

As severas punições no estilo de um bushi, impostas pelo pai, trouxeram resultado inverso: forneceram presas ao pequeno tigre. E quanto mais os aldeões o evitavam repudiando sua violência, mais vigoroso crescia, livre de peias, esse pequeno selvagem. (YOSHIKAWA, 2004, p.43).

As atitudes atrozes de Takezō faziam com que houvesse a necessidade daqueles que conviviam com ele de frear suas atitudes, impondo sucessivas regras que não o agradavam; desta forma, um círculo vicioso reinava na vila Miyamoto. Katō, ao discorrer sobre a fuga e o exílio, apresenta o ponto principal que levava um indivíduo a querer distanciar-se de sua terra, mesmo que temporariamente:

A comunidade garantia a segurança de seus membros. Enquanto tatemae (princípio social) protegia-os pelo menos de ameaças externas - por exemplo, da seca e dos impostos. Ao mesmo tempo, limitava ao extremo a liberdade individual deles, e essa pressão atingia todos os aspectos da vida diária, até os detalhes das ocasiões mais importantes de reuniões familiares, como os matrimônios e os funerais. Por isso, frequentemente, a produtividade do trabalho dentro da comunidade era elevada. Porém, para os indivíduos, isso era tão rígido quanto intolerável. (KATO, 2012, p. 253)

\footnotetext{
${ }^{12}$ Antes de ser rebatizado como Miyamoto Musashi, na vida real era chamado de Miyamoto Bennosuke 宮本弁之助, e no ficcional, de Shinmen Takezō 新免武蔵. Por isso, nesta dissertação, chamaremos o nosso herói de Takezō até adotar o outro nome.
} 
Com este panorama, podemos compreender que a vida em uma determinada vila obrigava o sujeito a abdicar de sua liberdade individual, com uma fundamentação voltada ao coletivo, com o objetivo de promover segurança àqueles que formavam tal comunidade. Desta forma, um sujeito encontrava-se entre manter seus desejos interiores vivos, mas, com a possibilidade de sofrer duras retaliações, ou obedecer às regras de convívio e perder sua liberdade individual. Com os ganhos que podem ocorrer quando se vive em harmonia numa comunidade, os indivíduos optam por um caminho aparentemente mais seguro, tornando-se assim seres coletivos, porém, perdendo as características pessoais que de fato os diferenciam.

Com uma postura de desobediência, Takezō parece protestar contra a supressão do indivíduo, mesmo que não entenda de fato os reais objetivos de suas atitudes. Não concorda em perder sua identidade e ser mais um em sua vila, obrigado a seguir todas as regras sem nenhum questionamento. As concepções de fuga e exílio refletidas por Katō giram em torno da obrigatoriedade a que o indivíduo é levado, mesmo sem ansiar, de seguir as regras da comunidade em que vive, para que só então seja socialmente aceito e inserido em tal grupo.

Os hábitos e as regras do grupo isolado e fechado a que se pertence em relação ao mundo exterior - como as típicas famílias de samurais do período Tokugawa, as comunidades mura e o país Japão -, ao mesmo tempo em que fortalecem a inclusão do indivíduo no grupo, podem restringir a liberdade, os sentimentos e as ações dos indivíduos, pressionando-os e destruindo-os. Aí, cria-se uma relação tensa entre a ordem do grupo e os anseios dos indivíduos que o compõem, e parece que, se a tensão aumenta, nasce o desejo de fugir desse grupo. (KATO, 2012, p. 269) 
Como resultado das inúmeras imposições que viera a sofrer por seu pai e conterrâneos da vila Miyamoto, somados às atitudes selvagens de Takezō, ele passa a ser um indivíduo marginalizado dentro da sua comunidade, seguindo uma direção totalmente oposta no que se refere às responsabilidades que deveria adotar em seu meio familiar e em uma posição correta e plausível em sua vila. Conforme Katō (2012, p. 272), o indivíduo sufocado por uma dificuldade crescente em tolerar o ambiente necessita decidir entre permanecer e adequar-se às regras, modificando o seu interior, ou deixar para trás sua terra natal. Compreendendo a impossibilidade de mudanças no comportamento de todos aqueles que o excluíam, nasce em Takezō o desejo de fuga. "[...] não ficarei nem mais um instante nesta vila horrorosa!" (YOSHIKAWA, 2004, p. 70). Como ocorreram diversas feridas ao longo de sua vida por meio destes embates, um sentimento de repulsa com relação à vila e seus moradores fez com que o protagonista não tivesse o menor interesse em mudar o seu interior e originou a necessidade de procurar o seu caminho longe dali.

Porém, o desejo não necessariamente promete sua real possibilidade. Pelo menos na prática, para fugir, é necessário, em primeiro lugar, ultrapassar as fronteiras e, em segundo, garantir o destino. Todavia, a falta de liberdade de acesso às fronteiras faz parte da ordem do grupo, e o desejo de fuga é gerado pelo fato de ser praticamente nula a possibilidade, legal ou ilegal, de mudança. (KATO, 2012, p. 269-270)

Katō apresenta este jogo entre o grupo e a restrição aplicada a seus componentes, de dificultar o desejo de fuga daqueles que a nutriam. Desta forma, Takezō, ao tentar partir de sua vila sem nenhum propósito, poderia ser confrontado sobre suas intenções e novamente ter sua liberdade restringida, impossibilitando-o de realizar sua fuga. Assim, para que pudesse burlar mais esta barreira, a única possibilidade encontrada pelo protagonista de ultrapassar as fronteiras e assim garantir 
o destino sem que houvesse restrições fora alistar-se ao batalhão do clã Toyotomi para a guerra de Sekigahara, que estava prestes a eclodir, idealizando que poderia, desta forma, utilizar de sua força para vencer o máximo de inimigos possíveis e alcançar glória e fama.

Pois sei que o senhor Shinmen Igankami, a quem meu pai serviu antigamente, é vassalo da casa Ukita. Calculei portanto que - embora eu seja filho de um simples goushi - seria admitido em seu quadro de samurai em consideração a esse antigo relacionamento e participaria desta guerra, bastando me apresentar a ele com uma lança na mão. Sonhava vencer um general em luta e exibir o grande feito à gente da nossa terra, que me considera um imprestável; queria também que Munisai, meu falecido pai, se orgulhasse de mim lá em seu túmulo... [...] (YOSHIKAWA, 2004, p. 23)

O objetivo que Takezō mantinha vivo dentro de si era somente o de provar o seu valor perante os outros, ao ser menosprezado por seus atos selvagens e estilo de vida inconsequente. Entretanto, para Katō (2012, p. 266), a realização da fuga não se configura realmente no exílio, pois somente a simples escolha de não querer pertencer mais a uma determinada comunidade pode-se mostrar um tanto quanto superficial. Mesmo que a idealização do protagonista fosse direcionada a um coletivo, esta não era exercida da maneira correta, constituída de uma intencionalidade rasa e de difícil conclusão. Os ganhos seriam somente troféus que apresentariam uma imagem superficial e as mudanças internas, de fato, não existiriam. Contrário ao que Musashi havia planejado, o lado pelo qual havia lutado na guerra acabara derrotado; com esta ocorrência foi obrigado a escapar como foragido, e após ser abandonado por Matahachi durante a evasão, sua única opção era retornar à sua vila. Esta ação, conforme Katō, demonstra uma característica de fuga, quando os objetivos "superficiais" não são realizados e há a necessidade do retorno à terra natal. 
Com a chegada de Takezō à sua vila, os aldeões articulam uma força tarefa para caçá-lo e aplicar punições estipuladas por eles mesmos, ou melhor, pela mandante do grupo em questão, a matriarca Hon'iden Osugi, a qual se mostrava a mais enérgica em desaprovar todas as atitudes do protagonista, além de colocar toda a culpa nele pela ida de seu filho Matahachi à guerra de Sekigahara e pelo fato de o mesmo não haver retornado, acreditando que havia morrido.

Esta idosa mãe, que nutria por Takezo um ódio perene, responsabilizando-o por haver aliciado o filho para a guerra, permaneceu em silêncio por instantes alimentando suspeitas infundadas. - O imprestável... Estou começando a achar que deixou meu fiIho morrer na guerra e agora, pressionado pelo medo, voltou sozinho para casa, o descarado - resmungou a velha. (YOSHIKAWA, 2004, p.63)

Todo o ódio expressado por Osugi reflete a ideia de que Takezō constituía-se como um indivíduo totalmente oposto aos objetivos da vila Miyamoto, e suas ações, vistas como selvagens, poderiam contaminar outros aldeões. Além disso, como ela mesma dizia, Matahachi havia sido aliciado para que fosse à guerra sem o consentimento de ninguém, e isto intensificou a ira contra o protagonista. A decisão da matriarca era de executar o protagonista caso fosse capturado por eles; assim chegaria ao fim toda a sua influência sobre os outros. "- Que ideia absurda! - gritaram unanimemente. - É claro que ele tem de ser executado! Não vale a pena soltar um homem tão perigoso, só nos trará aborrecimentos!" (YOSHIKAWA, 2004, p. 107) Conforme Katō (2012, p. 270), atitude semelhante era aplicada pela força militar no xogunato Tokugawa, reprimindo grupos que se rebelavam contra o sistema de imposições e ocorrendo a execução daqueles que eram considerados os líderes. Takezō também passa a ser procurado pelos soldados do clã Ikeda Te- 
rumasa ${ }^{13}$ (1565-1613) - a serviço do xogum Tokugawa Ieyasu 徳川家康 ${ }^{14}$ - , por ser fugitivo da batalha de Sekigahara e principalmente pelos "assassinatos" que vinha cometendo para que pudesse retornar à sua vila. "Os seguintes prêmios serão concedidos: - a quem o capturar -10 moedas de prata; - a quem o decapitar - 10 medidas de terra arável; [...]" (YOSHIKAWA, 2004, p. 77). Os aldeões, utilizando como justificativa o fato de que Takezō havia se tornado um criminoso, apoiam a sua execução, alavancados pela velha matriarca. Vila e governo, vistos como unidades que detêm um maior poder de controle sobre seus indivíduos, necessitam eliminar aqueles que são contra o sistema para que não possam "corromper" outros que se sintam sufocados com uma contínua restrição de liberdade.

Opondo-se a compactuar com as ideias dos soldados e moradores da vila de eliminar Takezō, o monge Sōhō Takuan vislumbra no protagonista uma má utilização de suas forças e inicia a busca por ele, para que pudesse realizar uma reestruturação do seu temperamento, podendo assim ser reinserido no convívio social de maneira mais amistosa. Este monge, pela construção de Yoshikawa, apresenta-se como um indivíduo excêntrico, mas portador de uma vasta erudição e com amizades influentes nas mais altas camadas da sociedade, aparentemente uma excepcionalidade por ter alcançado tamanho prestígio em tão pouco tempo de vida. A estratégia que o monge Takuan utiliza é totalmente oposta às tentativas anteriores; em nenhum momento seu objetivo é excluir o protagonista, mas sim compreender sua individualidade e apresentar rumos adequados a serem tomados em sua personalidade.

-Takezo, acho que você está cometendo um grande engano. Neste mundo há fogo, bebida, comida e até mesmo o calor da compaixão, caso você a busque. Não obstante, creio que você, por sua própria vontade, se lançou no inferno e de lá olha o

13 Daimiō com grande influência na região de Kansai.

${ }^{14}$ Fundador e primeiro xogum do Xogunato Tokugawa do Japão, que perdurou desde a Batalha de Sekigahara em 1600 até a Restauração Meiji em 1868. 
mundo sob um prisma distorcido - não é assim? Bem, não vou discursar mais. Em seu atual estado, razões não devem interessar. Vamos, aproxime-se do fogo e aqueça-se. (YOSHIKAWA, 2004. p. 102-3)

Para que pudesse localizá-lo e capturá-lo, Takuan faz com que Takezō sinta-se confortável para se aproximar, já que havia sofrido anteriormente algumas emboscadas. A tensão que existia entre o protagonista e o mundo era extremamente forte, e o que ele precisava não era de mais atrito. Takuan teve a sutileza de adotar esta abordagem e trazer o jovem até ele. Mas após prendê-lo, inicialmente o monge, frente ao culpado, se mostra um tanto quanto inflexível e intransigente, aparentando ser um reflexo do protagonista e dos moradores da vila Miyamoto.

Céus, que força impressionante! Você está conseguindo balançar até a árvore! Mas veja a terra: nem se abala, reparou? Sabe por quê? Porque não há força em seu ódio - seu ódio é pequeno, é privado, tem origem em rancores pessoais. A indignação de um homem deve ser desprovida de interesses pessoais, devotada à causa pública. Encolerizar-se levado por mesquinhas emoções pessoais é histeria feminina. (YOSHIKAWA, 2004, p.122)

Aos poucos Takuan vai implantando um desejo de humanização em Takezō, de forma que a saída é remanejar todas as forças em objetivos sólidos, e não desperdiçá-las irracionalmente. O monge enxerga o potencial do protagonista, mesmo tendo uma opinião criada a partir da perspectiva dos moradores do vilarejo, mas inicialmente tem uma postura rígida, para mostrar que existe outro meio - o intelecto - que sobrepõe a força física e que este é um forte aliado para se emancipar dessas camadas que são de certo modo fechadas e discriminatórias. Até então, Takezō só havia se confrontado com indivíduos, de tal forma, inferiores em relação à força física e assim, como consequência, os 
mesmos foram excluindo-o do meio em que vivia por não seguir os padrões desejados. Há um duelo intelectual entre os dois, e claro que o jovem sai derrotado nas diversas vezes em que o monge vai defrontálo; aos poucos ele vai abrindo os olhos, ou melhor, vai iluminando o raciocínio do protagonista no que diz respeito a querer direcionar e tomar atitudes coerentes em relação a sua vida. Para começar a tomar esses tipos de atitudes, só haveriam dois caminhos: adequar-se ou partir; a primeira opção, sem sombra de dúvidas, estaria fora de cogitação, pois desejavam sua morte. E para trilhar um novo caminho, criar uma nova história e seguir preceitos corretos, seria necessário partir e imergir no exílio, manter-se em deslocamento físico e psicológico em relação àqueles que não o queriam, a ideia mais sensata que Ihe surgira.

Para que Takezō pudesse partir, o monge Takuan, ao levá-lo ao suserano Ikeda Terumasa, decide que ele deveria pagar por seus crimes, sendo mantido preso por exatos três anos. Mas sua cela não era nada convencional, pois ela estava repleta de livros - literários, históricos etc. - para que Takezō pudesse absorver todo aquele conhecimento que estava à sua disposição. Através da educação poderia tornar-se um indivíduo diferente, conhecedor de diversas verdades e realidades, assim desvencilhando-se de certos dogmas perpetuados a fim de manipular os indivíduos que compõem uma determinada sociedade.

Após os três anos de encarceramento, Takezō sai como um indivíduo totalmente diferente; o objetivo do monge havia sido alcançado com êxito. Para que o protagonista pudesse gozar uma nova vida de forma mais tranquila, o suserano Terumasa e o monge Takuan decidem rebatizá-lo.

- Uma vida errante durante a mocidade não deixa de ser interessante. Apesar disso, para que nunca esqueças tuas origens e tua terra natal por onde quer que andes, vou dar-te um novo sobrenome: Miyamoto, em homenagem à tua vila natal. A partir de hoje, pássaras a te chamar Miyamoto, pois eu assim te no- 
meio: Miyamoto! - disse Terumasa. [...] A seu lado, Takuan acrescentou: - Nesse caso, vamos mudar também a leitura de seu nome: conservando-se as mesmas letras, que sejam lidas de um novo modo - Musashi. Saído do ventre da escura cela, hoje é o seu primeiro dia no mundo da luz. Melhor será que se renove inteiramente. (YOSHIKAWA, 2004, p. 148)

A partir deste momento, Musashi, e não mais Takezō, ganha a oportunidade de renovar-se e vivenciar todas as experiências que o mundo poderia Ihe oferecer. Ele estava livre para partir rumo ao desconhecido, mas como o próprio Terumasa ressaltou, não poderia esquecer sua origem, ligada ao seu passado, e dela retirar lições para que não viesse a repetir os mesmos erros.

- Porque hoje, enfim, sou um novo homem: passei pela experiência da morte, renasci e, neste exato instante, estou decidido a dar o primeiro passo no longo e difícil caminho dos que buscam aperfeiçoar-se. (YOSHIKAWA, 2004, p. 150)

Decidido a trilhar um rumo para sua vida longe de sua terra natal, Musashi visa, inicialmente, seu desenvolvimento no caminho da espada até alcançar a maestria. Entretanto, sua renovação não é integral; mesmo portando uma nova identidade, ele deverá carregar em seu íntimo todas as experiências obtidas na vila Miyamoto por Takezō. "As realizações do exílio são permanentemente minadas pela perda de algo deixado para trás para sempre." (SAID, 2003, p. 46) Conforme Said, o protagonista deixará tudo para trás, cortando os últimos vínculos que possam impedi-lo de viver uma nova vida. Mas o seu passado, mesmo que indiretamente, estará presente para que o mantenha engajado nos objetivos que pretende alcançar.

Até o momento do seu encarceramento, Musashi e as pessoas que o cercavam encontravam-se em um grande embate referente ao estilo de vida a ser seguido e o que deveria ser tomado como certo ou 
errado. Assim, o protagonista, não seguindo os preceitos básicos daquela comunidade, fora então marginalizado, e acabara por intensificar sua marginalização ao enfrentá-los. Agora, com uma nova oportunidade, escolhe voluntariamente por afastar-se. Além disso, a todo momento Musashi prefere estar à margem de tudo em que venha a se envolver; mesmo que algo o force a direcionar-se ao centro, poderemos ver suas escolhas de exercer algo como um autoexílio. Esta atitude não se assemelha às suas atitudes do passado, mas sim a uma ideia de espectador, absorvendo tudo aquilo que acreditava ser útil ao seu desenvolvimento.

\subsection{RECOMEÇO}

Desta forma, agora Miyamoto Musashi parte como um shūgyōsha - entende-se como um espadachim em treinamento que viaja pelo país e segue seu próprio caminho, afim de estabelecer neste aprendizado uma escola ou estilo. Por decisão própria decide partir, mas ao mesmo tempo, com uma condição de exilado pelo próprio povo, de forma que todo o território japonês apresenta-se como uma fonte inesgotável de possibilidades para o seu crescimento.

No fim das contas, o exílio não é uma questão de escolha: nascemos nele, ou ele nos acontece. Mas desde que o exilado se recuse a ficar sentado à margem, afagando uma ferida, há coisas a aprender: ele deve cultivar uma subjetividade escrupulosa (não complacente ou intratável). (SAID, 2003, p. 57)

Para Said, compreende-se o exílio como uma situação espontânea ou forçada, revelando opções àquele que o vive. Logo, a escolha ou imposição de partir ou ficar somente trará respostas e resultados posteriormente, e dependerá unicamente do esforço ou não empregado pelo indivíduo para que sejam alcançados tais resultados. Além disso, é possível observar no romance não só o desenvolvimento e dificuldades na 
vida de Musashi, mas também com Matahachi, Otsū, Osugi e outros que cruzarão o caminho do protagonista. Podemos compreender que a proposta de Yoshikawa Eiji de levar outros personagens a uma viagem, juntos mas separados de Musashi, tem como objetivo mostrar como cada um lidou com as oportunidades da vida. Desta forma, não há somente um modelo a ser mostrado, mas vários e de diferentes índoles, assemelhando-se a uma comparação do que é certo e errado a ser seguido. Não estará incluído no cerne deste trabalho aprofundar o estudo das trajetórias dos outros personagens de maneira minuciosa. Entretanto, a fim de elucidar a progressão de Musashi, será necessário apresentar aos poucos o desenvolvimento dos outros personagens importantes para o romance, tendo em vista que são eles as grandes influências, mesmo que indiretamente, para o herói.

O primeiro grande desafio na nova vida do protagonista ocorre quando entra em contato com o clã Yoshioka, para ter embates e discussões sobre o caminho da espada. Porém, ao identificar-se como um simples rōnin ${ }^{15}$ 浪人 e autodidata excêntrico, sofre um certo preconceito por parte dos componentes do clã.

- Sou autodidata - respondeu Musashi. - Em criança, tive algumas aulas de jitte-jutsu com meu pai, mas confesso que não me empenhei nos estudos. Mais tarde, com a maturidade, passei a considerar mestres todos os seres do mundo e todos os guerreiros veteranos do país, deles extraindo diversos ensinamentos. (YOSHIKAWA, 2004, p. 242)

Ao denominar-se de forma franca, Musashi sofre com julgamentos de pessoas que nunca vieram a lhe conhecer, dificultando o seu contato com aqueles que tinha desejo de encontrar e poder trocar conhecimentos.

\footnotetext{
${ }^{15}$ Nome empregue aos guerreiros e samurai que ficaram sem mestre ou senhor por causa da conquista ou da desapropriação de seus territórios.
} 
Só o fato de surgir maltrapilho nos portões da academia considerada a melhor do país já demonstrava falta de savoir-faire, achavam; mas pretender estabelecer estilo próprio, como o mestre Kenpo, demonstrava tamanha ignorância das próprias limitações que chegava a ser cômico. Alguém sugeriu, em tom de troça, que o atendente fosse perguntar-Ihe a quem deveriam entregar seu corpo em caso de morte. (YOSHIKAWA, 2004, p. 186)

Com tais julgamentos superficiais, uma nova barreira é construída entre o protagonista e aqueles com quem gostaria de interagir. Estas pessoas do clã, já tendo experiências com indivíduos parecidos com o protagonista, não têm o menor interesse em relacionar-se com este, que aparentemente está em um nível inferior. "E logo adiante da fronteira entre "nós" e os 'outros' está o perigoso território do nãopertencer [...]" (SAID, 2003, p. 50). Conforme Said, um sujeito que esteja em exílio sofrerá dificuldades de conviver naturalmente em qualquer lugar em que venha a se instalar. Desta forma, será primordial como ocorrerá a adaptação e a aceitação do sujeito no novo grupo ou lugar. Com um resultado favorável, mesmo sendo um forasteiro, poderá fazer parte do grupo enquanto seguir as regras. No entanto, ao ser negado por incompatibilidade, vem a ser inserido como um desqualificado que não terá a permissão para pertencer a tal meio. No momento do romance citado acima, Musashi não aparentava nem demonstrava ser um espadachim convencional conforme o senso comum. Assim, o clã Yoshioka, ao discriminá-lo, rotula-o numa camada não pertencente a sua classe guerreira como uma forma de exílio.

Desta forma, por não atender a supostos requisitos, o protagonista, julgado como um indivíduo sem uma formação clássica - aqui, a formalidade é ter um mestre -, é menosprezado pelo clã de renome. "O exílio tem origem na velha prática do banimento. Uma vez banido, o exilado leva uma vida anômala e infeliz, com o estigma de ser um forasteiro." (SAID, 2003, p. 54). Divergindo da "prática de banimento" 
citada por Said, mas concordando com esta ideia geral, Musashi não é banido da camada dos espadachins, mas sentenciado a permanecer à margem desta, por demonstrar uma personalidade anormal. É possível compreender, no romance, que cada indivíduo necessita estar sempre em consonância com a sua classe, havendo a mínima possibilidade de mobilidade do mesmo. Esta questão não será tratada diretamente neste trabalho, mas com a leitura do romance e durante o mesmo, será possível perceber as dificuldades que o protagonista sofre para ser reconhecido como um legítimo espadachim. Inclusive, ele próprio não demonstra nenhum interesse em estar atrelado a alguma escola na necessidade de absorver conhecimento. Deste modo, estar à margem será um facilitador para que Musashi possa colher somente o necessário para compor seu estilo, sem que haja influências diretas de outros estilos sobre o seu.

Existe uma grande diferença entre Musashi e os indivíduos do clã Yoshioka; o primeiro, portando um espírito humilde e sincero, delimitou o seu caminho em busca de um contínuo aprendizado - "A mim, Musashi, obscuro e ignorante, submetei à provação e fazei de mim o meIhor espadachim da face da terra; ou senão, deixai-me morrer." (YOHIKAWA, 2004, p. 196) -, enquanto os outros, cegos pela fama que obtiveram com os esforços dos antepassados, viviam quase que exclusivamente para aproveitar o que esta condição, conquistada no passado, Ihes favorecia.

E enquanto no interior da academia os orgulhosos membros do clã se vangloriavam e se divertiam, o tempo passara fora daqueles extensos muros brancos e operara uma invisível transformação. Foi assim que, despertados do glorioso sonho em que a presunção os havia mergulhado, tinham ido naquele dia ao encontro do desastre pela espada de um obscuro provinciano de nome Miyamoto Musashi. (YOSHIKAWA, 2004, p. 184-5) 
Rechaçado, como mostra a citação acima, Musashi tem a oportunidade de alguns embates preliminares, nos quais os componentes do clã pressupunham que a vitória seria certa e findaria de uma vez por todas a vida deste "ignorante" adversário. Entretanto, nenhum daqueles indivíduos, com uma postura arrogante, esperava um resultado contrário.

Pretendiam admiti-lo no salão de treinos, talvez aleijá-lo, e expulsá-lo em seguida. Todavia, já no primeiro duelo, aleijado ficara um dos discípulos da academia, cujo braço fora quebrado pela espada de madeira usada em treinos. O braço não fora apenas quebrado, mas quase arrancado: a mão do homem pendia, presa apenas à pele do pulso. (YOSHIKAWA, 2004, p. 185)

Embora este combate tenha ocorrido contra alguns integrantes pouco graduados, foi o suficiente para evidenciar a disparidade entre Musashi e o clã. Como o próprio título deste capítulo sugere, "Roda da Fortuna", haverá grandes mudanças para ambos os lados. O clã Yoshioka caminhará para sua ruína, mas até que isto aconteça por completo, causará incômodos direta e indiretamente no protagonista, os quais perdurarão até quase a conclusão do romance. Em contrapartida, Musashi começará a ganhar notoriedade com esta relação, mas enfrentará diversos obstáculos desleais em razão da exacerbada arrogância que seus adversários defendiam.

Musashi e Yoshioka Seijurō, atual mestre do clã, acordam em realizar o embate um ano após este fatídico encontro. Com esta oportunidade, o protagonista empreende uma nova viagem pela região de Kansai ${ }^{16}$ com o objetivo de preparar-se, além de entrar em contato com diversos estilos de combate e experiências.

16 Fazem parte da região as províncias de Nara, Wakayama, Quioto, Osaka, Hyōgo e Shiga. 


\subsection{FRÁGEIS RAÍZES}

Um fato relevante neste período de um ano acontece quando o protagonista retorna a Quioto para o seu embate, mas antes procura a sua tia materna em busca de abrigo e acolhimento. Novamente, Yoshikawa Eiji nomeia este capítulo com um título bastante expressivo, "Solidão". Musashi, ao reencontrar sua tia, é recebido com tamanha frieza que, ao pernoitar em sua casa, fica totalmente desconfortável. Apesar de a realidade deste acolhimento não condizer com a expectativa, principalmente por ter uma ligação sanguínea, era crucial desfrutar de um mínimo de conforto para estar revigorado antes de seu embate. Ao escolher exilar-se, Musashi prioriza seu desenvolvimento marcial proporcionalmente com a mesma intensidade que suprime a sua vontade de nutrir relações afetivas. Sua peregrinação solitária faz com que haja, uma hora ou outra, uma recaída no desejo de sentir-se acolhido. Contudo, em um dado momento no capítulo em questão, Musashi reflete sobre esta situação:

Continuo confiando demais em coisas como laços sanguíneos. Vivo dizendo a mim mesmo que sou só no mundo, que posso contar apenas comigo mesmo, e quando menos espero, cá estou eu, tentando depender de alguém. Sou tolo, muito ingênuo, tenho de crescer! (YOSHIKAWA, 2004, p. 580)

Até então, o protagonista mostrava-se bastante resolvido com a opção de vida que viera a adotar. Mas este encontro, ocorrido de forma ocasional, evidencia as adversidades sentimentais pelas quais um exilado pode vir a passar. "Ela é uma fratura incurável entre um ser humano e um lugar natal, entre o eu e seu verdadeiro lar: sua tristeza essencial jamais pode ser superada." (SAID, 2003, p. 46). De acordo com Said, o indivíduo, enquanto permanece nesta condição, carregará em seu íntimo, demonstrando ou não, o seu abatimento em ter de viver excluso. $\mathrm{E}$ 
esta dor, como ressalta, carece de possibilidades de resolução. Mesmo Musashi não desejando voltar à sua terra natal, a procura por sua tia pode demonstrar a falta de alguns aspectos que sua vida passada lhe trazia.

Saiu a seguir para o mundo ainda escuro apesar da chegada do novo ano, e seguiu caminho cabisbaixo, pisando a fina crosta de gelo que recobria a terra, um vulto triste e friorento lembrando um pássaro sem penas vagando no inverno. (YOSHIKAWA, 2004, p. 582)

Durante todo o romance, constatamos que a trajetória de Musashi é constantemente solitária, apesar do fato de ele constantemente relacionar-se com um personagem ou outro. Entretanto, neste trecho em especial, Yoshikawa constrói uma cena um tanto quanto significativa, um Musashi que enfim compreende o quão só está no mundo. O último laço familiar, assim como afetivo, desaparece. Mais uma vez, era um momento para renovar-se e aceitar as possibilidades oferecidas por estar imerso no exílio.

- É porque o frio está no coração, e não no corpo - descobriu Musashi. - Para começar, tenho ainda em mim essa carência que me leva às vezes a ansiar por afeto, como se eu fosse um bebê e buscasse o calor materno. Isso me leva a sentir solidão, a invejar o calor que ecoa pelas janelas dos lares alheios. Por que não me orgulho desta solidão e desta vida nômade que me foram concedidas? Por que não as considero ideais e não agradeço aos céus por elas? (YOSHIKAWA, 2004, p. 583)

Desta forma, ele reflete que existe a necessidade de reafirmar sua condição de exilado, além de romper com o desejo de buscar um conforto afetivo quando sentir-se só. Em troca disto, deve agradecer a oportunidade de poder conhecer o mundo - aqui o Japão da sua época 
- e entrar em contato com culturas e vivências diversificadas que poderão agregar conhecimentos para a sua formação.

Após este capítulo, estava aproximando-se o dia do grande embate entre Musashi e Yoshikawa Seijurō. Enquanto o protagonista circulava pela cidade de Quioto, à sua espreita estava a matriarca da família Hon'iden, esperando um momento oportuno para cumprir com suas próprias mãos a vingança ansiada. Com todo o incômodo que ela vinha infligindo na vida de Musashi, era esperado que o antigo Takezō rebatesse todas as injúrias com extrema selvageria. Entretanto, a postura do protagonista era totalmente oposta.

Na verdade, Musashi é quem devia odiá-la, e não Osugi a ele. O ódio que Osugi lhe devotava - intenso a ponto de fazê-la jurar-lhe inimizade por todas as sete reencarnações a que uma alma está destinada - tinha origem em mal-entendidos e em confusas emoções que, uma vez esclarecidos, deveriam promover o entendimento. Mas Musashi poderia explicar-lhe as razões um milhão de vezes e ainda assim não lograria fazê-la esquecer a vingança cuidadosamente planejada [...] (YOSHIKAWA, 2004, p. 587)

Obcecada por uma falsa verdade, a velha matriarca, mesmo que viesse a tomar conhecimento dos fatos tais como realmente aconteceram, não pretendia retroceder com sua vingança. Sua perseguição desenfreada somente intensificaria o isolamento que Musashi vinha e viria a sofrer a partir deste ponto. Mesmo o protagonista afastando-se da busca de conhecimento tradicional e principalmente das relações humanas, por iniciativa própria, sempre haverá um agente que forçará a saída de Musashi da margem para o foco dos acontecimentos. Assim como Osugi, outros personagens terão a mesma função, intensificados a partir dos embates com o clã Yoshioka. 


\subsection{O INÍCIO DE UM NOVO ÓDIO}

Mesmo que o embate entre Miyamoto Musashi e Yoshioka Seijurō houvesse sido divulgado como um evento público, este viera a acontecer de forma bastante privada. Para manter a ética no combate, Seijurō decidira secretamente manter o seu clã afastado para que não ocorresse nenhuma intromissão indesejada. Por fim, a vitória de Musashi após um único golpe faz com que coexistam algumas repercussões: uma postura que exprime como sua maturidade desenvolvera-se desde que fora enclausurado; além disso, a ousadia cedera lugar a um indivíduo mais reflexivo.

Só mentes guerreiras mais evoluídas são capazes de sentir tristeza depois de uma vitória. Principiantes, estudantes de artes marciais, desconhecem esta sensação. Musashi, caminhando agora sozinho pela campina sem fim, sentia uma opressiva tristeza a envolvê-lo. (YOSHIKAWA, 2004, p. 637).

Mais uma vez, o protagonista mostra-se um indivíduo com qualidades além do esperado, com uma tendência a distanciar-se dos seus adversários, quase como uma impossibilidade em poder equipará-los. E mesmo que os fatos subsequentes entre ele e o clã Yoshioka tornem-se uma dificuldade vivida diariamente, podemos compreender o progresso que está intimamente interligado: o crescimento da proporção entre os obstáculos e sua evolução. Entretanto, o desenrolar da repercussão deste embate respingará por todo o romance; mesmo que um ciclo aparentemente se dê por concluído, ainda existirá influência deste episódio. Além disto, o clã que ruirá será outro significativo agente que implicará no exílio constante do protagonista.

Portanto, Musashi estava predestinado a embater-se com cada um que carregasse o desejo de aniquilá-lo para apagar qualquer mácula de humilhação que o clã Yoshioka acreditava ter sofrido em suas mãos. 
- Os discípulos estão furiosos e dizem que vão acabar com Musashi de qualquer jeito, para não ter de fechar a academia. Mas o único capaz de enfrentar um homem que nem Seijuro conseguiu vencer é o mais novo dos Yoshioka, Denshichiro. Dizem os boatos que os discípulos o procuram feito loucos. (YOSHIKAWA, 2004, p. 655)

Como é apresentado no romance, a opinião popular favorece o engrandecimento da rivalidade entre o protagonista e o clã. As pessoas começam a tomar conhecimento de um suposto desempenho de ambos os lados e iniciam-se rumores que podem pressionar aquele que estiver mais fragilizado. Neste momento, Musashi encontrava-se retirado, de tal forma encouraçado, contra qualquer que fosse o julgamento. Antes, enquanto sua identidade era Takezō, o seu desenvolvimento tinha como intuito se exibir a todos, como forma de autoafirmação perante os outros. Agora, auto exilando-se, de uma maneira levava a si próprio à margem; desenvolve-se ao mesmo tempo em que opta por preservarse. $O$ interesse de Musashi não é externalizar o seu crescimento como um triunfo a ser admirado por onde passa.

Por outro lado, a opinião popular teve o poder de pressionar o tradicional clã, já situado numa situação complicada. Denshichirō, o sucessor do clã Yoshioka, se intitula o próximo oponente, com uma prepotência alicerçada no status que a família detinha, assemelhando-se ao erro que o irmão mais velho havia cometido.

- Que é isso, meu irmão? É mais do que óbvio que eu queira bater-me com ele, a esta altura dos acontecimentos! E não foi para isso que me mandou buscar? Ainda não se tinha dado conta de que seus discípulos e eu largamos tudo e viajamos incontinentes noite adentro porque queríamos pegar Musashi antes que ele fugisse para outra província? Ora essa! (YOSHIKAWA, 2004, p. 693) 
Aparentemente, Denshichirō seguia para um caminho mais obscuro do que seu irmão; a obrigação em limpar o nome da família estava cegando-o, sem que ele de fato ponderasse sobre a sua atual condição e como a recente luta havia chegado naquele desfecho. Ele, assim como os outros componentes do clã, não aceitava que um indivíduo interiorano poderia superar anos de tradição sem ser portador de uma história de renome. Entretanto, Seijurō, momentos antes do encontro com seu irmão, ponderava enfim sobre os resultados.

Foi muita pretensão de minha parte. Como se a reputação de meu pai pudesse de algum modo ser minha! Pensando bem, que fiz eu para merecer o nome do meu pai, afora ter nascido seu filho? Muito antes de ser derrotado por Musashi, eu já estava destinado à derrota, como homem e como líder de um clã. 0 duelo com Musashi apenas apressou o desfecho final, a minha destruição. Cedo ou tarde ela viria. Esta academia não poderia continuar sendo a única a prosperar para sempre, à margem da correnteza que assola a sociedade estes dias. (YOSHIKAWA, 2004, p. 690)

Seijurō, dessa forma, percebe que a sua derrota não estava estritamente ligada ao fato de Musashi ser mais ou menos habilidoso do que ele, mas sim a como ele lidava com toda a - ou falta de - responsabilidade de carregar o nome que seu pai havia erguido. O nome ou clã Yoshioka tinha uma grande contribuição para a esgrima daquele período, porém a história não poderia ser um peso determinante no resultado de um embate, e fora isto que deveria ter sido respeitado desde o princípio. Desqualificar Musashi somente por ele não carregar uma tradição foi afirmar que o clã já estava em processo de derrocada, antes não tendo a sua devida importância ponderada.

Enquanto a situação tornava-se mais complicada para o clã Yoshioka, Musashi recebia, aos poucos, o reconhecimento de indivíduos que circulavam nas castas mais importantes da sociedade japonesa. O pri- 
meiro sinal de reconhecimento viera do suserano Ikeda Terumasa, quando permaneceu preso por três anos. Agora encontrava-se hospedado na residência de Hon'ami Kōetsu (1558-1637) - polidor de espadas, ceramista, calígrafo e projetista célebre entre a família imperial. Este fora novamente um momento para entrar em contato com as artes e expandir seus conhecimentos. Aparentemente são nestes momentos que Musashi renova-se e cresce como indivíduo, transitando em meios em que indivíduos por assim dizer excêntricos são reconhecidos e bem aceitos.

Em uma discussão sobre pinturas e em receber uma como presente, o protagonista é indagado por Kōetsu sobre a possibilidade de vir a instalar-se em Quioto. Ele responde de tal maneira:

- Nunca senti falta de uma casa até hoje. Considero muito mais atraente a possibilidade de conhecer os confins de Kyushu, a civilização de Nagasaki, a cidade de Edo que começa a se expandir a leste do país - e que, assim me dizem, será a nova sede xogunal -, bem como os vastos rios e montanhas que cortam a área de Michinoku. Por esses lugares distantes anseia meu coração. Talvez eu seja um nômade nato. (YOSHIKAWA, 2004, p. 739)

Já há alguns anos longe de sua terra natal, Musashi mantém-se firme naquilo que acredita e na sua escolha de estilo de vida. Não necessita ter uma casa para sentir-se bem, pois ele busca a satisfação de viver ao desbravar o Japão, muito além das fronteiras físicas. Como foi possível notar, o protagonista, ao sofrer com diversas formas de exclusão antes do início da vida adulta, teve como resultado a opção de partir de sua terra natal. Entretanto, sua decisão de se afastar apresentava-se constantemente como algo realmente positivo. "Às vezes, o exílio é melhor do que ficar para trás ou não sair: mas somente às vezes." (SAID, 2003, p. 51). Enquanto para a grande maioria, segundo Said, o exílio será algo tão insuportável quanto ficar e enfrentar ou adaptar-se 
em seu berço. Entretanto, o indivíduo, ao extrair as melhores possibilidades durante o exílio, poderá diminuir as adversidades a que esta condição tende a arrastá-lo. Ser uma exceção dentre milhões que já vivenciaram é uma tarefa totalmente árdua; além do trauma em encontrarse desterrado, existirão sucessões de acontecimentos aterradores. A partir deste ponto de vista proposto por Said, mesmo não sendo a proposta desta dissertação, possibilita-se analisar a trajetória dos demais personagens que compõem este romance.

Como réplica ao posicionamento do protagonista, Kōetsu tenta persuadi-lo com sua perspectiva:

- Somos todos iguais. É natural um jovem sentir-se mais atraído por espaços abertos do que por uma apertada sala de chá. Ao mesmo tempo, um jovem tem o péssimo hábito de achar que não pode realizar seus sonhos no lugar onde está, e de sempre buscá-los por caminhos distantes. Grande parte dos preciosos dias da juventude se perde nessa insatisfação. (YOSHIKAWA, 2004, p. 739)

Neste momento podemos comparar as opiniões de ambos os personagens. Kōetsu, um indivíduo já inserido e respeitado dentro do seu meio, não enxerga a necessidade que alguns jovens têm em buscar instruções em terras alheias, acreditando que poderiam construir suas vidas no local onde se encontram. Entretanto, este senhor que viera de uma família prestigiada não aparenta compreender a escassez de oportunidades que existem para alguns jovens, principalmente interioranos - assim como Musashi. Além disto, a escolha por caminhos distantes nem sempre vem amparada por uma trajetória estável. Pode haver uma grande variação de altos e baixos que influenciarão na formação de cada indivíduo, e dependem, em sua maioria, única e exclusivamente da maturidade para lidar com todos os acontecimentos.

Contudo, esta discussão é encerrada de forma brusca, sem que haja uma troca de argumentos mais concreta, talvez como uma escolha 
de Yoshikawa Eiji em apresentar de forma diluída os passos do protagonista e deixando para o leitor o trabalho de ponderar pensamentos como o de Hon'ami Kōetsu. Por fim, o senhor Kōetsu convida Musashi para que fossem fazer uma visita à zona de prazeres para desfrutar a noite com a presença de outro senhor, mas o jovem simplesmente nega por não condizer com seus princípios; acreditava que frequentar estes lugares condizia com entregar-se à perdição. Contudo, fora persuadido - não por Kōetsu, mas pela mãe dele, o que o surpreendeu mais ainda -, para que viesse a conhecer e aproveitasse este momento único.

Antes que chegassem à zona de prazeres, Musashi é abordado por discípulos do clã Yoshioka com os termos da próxima luta, ocorrendo entre as primeiras horas da noite. Mas antes que o embate viesse a acontecer, durante a noitada, ele é tratado como convidado de honra por aqueles que estavam no recinto. Não se sentindo totalmente confortável com tamanho entusiasmo por parte daqueles senhores tão refinados, começa a entediar-se com o desdobramento daquele momento.

\footnotetext{
Os exilados olham para os não-exilados com ressentimento. Sentem que eles pertencem a seu meio, ao passo que um exilado está sempre deslocado. Como é nascer num lugar, ficar e viver ali, saber que se pertence a ele, mais ou menos para sempre? (SAID, 2003, p. 54)
}

Conforme Said, há uma diferença entre exilados e não exilados no que se refere ao sentimento de pertencimento. Indivíduos não exilados, como os anfitriões de Musashi, fazem com que este novo indivíduo se sinta inserido naquele meio. Desta forma, é natural que seja apresentado algo em especial do grupo para que possa atrair o interesse do indivíduo. No romance, a companhia de artistas, numa noite na zona de prazeres para desfrutar de um bom saquê e assistir diversas apresentações de gueixas, principalmente das mais refinadas, configura-se em um meio habitual para as classes mais elevadas na sociedade japonesa. 
Neste tipo de noites, podem ocorrer efusões artísticas únicas, como o que ocorre naquele momento em questão. Por outro lado, a um exilado, mesmo que compartilhe de hábitos semelhantes, pode ocorrer de não se sentir sintonizado a todo o momento nem em todos os lugares. Para Musashi, desde o seu primeiro contato com as letras, o seu interesse por outras artes, além da marcial, foi ampliando. Porém, sua vontade inicial não era estar naquele lugar e conforme as situações iam progredindo, a sensação de isolamento começava a manifestar-se nele e também naqueles que o convidaram.

Com a aproximação do horário do embate, Musashi, em uma brecha, retira-se sem que fosse notado, ao mesmo tempo em que o faz de forma atenciosa para não atrapalhar a noite dos entretidos senhores. A atmosfera estava prestes a mudar drasticamente; enquanto compartiIhava da companhia de pessoas que compunham a aristocracia, era respeitado e até igualado em questões artísticas. Entretanto, os próximos momentos estavam na iminência de retornar ao que Musashi já estava acostumado a vivenciar todos os dias.

\footnotetext{
"Ah, maldito!", pensou Denshichiro mal pôs os olhos em Musashi, examinando-o com ódio desde o topo da cabeça até a ponta dos pés. Raiva pelo que Musashi fizera ao irmão, irritação pelas vexatórias comparações que circulavam pela cidade, e o desprezo preconcebido pelo "novato provinciano", subiram num átimo à cabeça. (YOSHIKAWA, 2004, p. 772)
}

Denshichirō, assim, carrega uma enorme carga negativa contra Musashi, acreditando que todos os problemas que pairavam sobre o clã Yoshioka haviam sido gerados exclusivamente com o surgimento deste "novato provinciano". Mas todo o cenário desfavorável presente representava a incorreta condução do célebre clã que acreditava no mantimento do prestígio somente com os frutos da tradição. Por outro lado, Musashi, como um indivíduo solitário, sem de fato ser detentor de uma 
história, sente-se menos pressionado para o embate. Além disto, o preparo de ambos era totalmente diferente.

Falando em buscar o momento favorável, Denshichiro ainda estava no estágio inicial da batalha, sentindo os primeiros frêmitos percorrerem-Ihe o corpo ao pôr os olhos em Musashi; este, porém, já se sentia em guerra muito antes de aparecer diante de Denshichiro e ia agora a meio no caminho da batalha. (YOSHIKAWA, 2004, p. 773)

Por todo o romance, mas em especial com esta citação, podemos observar que Musashi encontra-se em constante estado de alerta, como se realizasse um esforço para não deixar a guarda abaixada em qualquer que fosse o momento. Em situações mais cotidianas isso faz com que ele crie um distanciamento das pessoas. Possivelmente o protagonista utiliza disto para que possa estar atento a qualquer estímulo que surja. Já Denshichirō, por vir de um aprendizado clássico, necessita atravessar algumas etapas até ficar pronto para o embate.

O resultado viera como a derrota do irmão mais velho de Denshichirō; numa rapidez e precisão que até o próprio narrador não conseguira acompanhar, mais um Yoshioka tombava sob os pés de Musashi. Desta forma, os discípulos do clã, ao se encontrarem com o protagonista, desejavam somente uma coisa:

— Você não pode aleijar nosso mestre, Seijuro, eliminar seu irmão mais novo, Denshichiro, e continuar vivo: nós, discípulos da academia Yoshioka, não permitiremos. Por sua causa, o nome Yoshioka foi arrastado na lama, mas os cento e poucos discípulos leais ao seu mestre aqui estão para vingá-lo. Isto não é um acerto de velhas contas promovido por um bando de homens ressentidos, e sim uma guerra de extermínio, destinada a lavar a alma de nosso mestre. Sinto por você, Musashi, mas sua cabeça já nos pertence. (YOSHIKAWA, 2004, p. 833) 
Mesmo após duas vitórias legitimas, Musashi ainda continuava sendo julgado como alguém desonesto e traiçoeiro. Tais julgamentos oriundos do clã Yoshioka assemelham-se aos dos seus contemporâneos da vila de Miyamoto. Por não compactuar com as ideias vigentes - da vila e clã -, não intencionalmente o protagonista exerce a função de escancarar a verdadeira face daqueles que, doutrinados em uma falsa ilusão, acreditam viver em um mundo harmonioso. Entretanto, o coletivo direciona suas forças contra o indivíduo para conter essas afrontas. Mais uma vez, a ideia de aniquilar o corruptor é defendida por todos como a solução mais correta.

Tudo indicava que uma atrocidade desleal contra Musashi poderia acontecer a qualquer momento, mas como o clã tinha o mínimo de consciência em relação à opinião pública, decidiram acertar um novo embate conforme as formalidades determinavam. O próximo adversário era o menino Genjirō, primo de Seijurō e Denshichirō e próximo herdeiro da família Yoshioka.

Desta vez, os próprios componentes do clã começavam a ter percepção da real situação em que se encontravam:

- A casa Yoshioka está decadente, não há mais dúvida! Também, não era para menos: perdemos dois pilares de sustentação, os senhores Seijuro e Denshichiro. É desse jeito que acontece a queda de uma casa tradicional! (YOSHIOKA, 2004, p. 856)

Pelo menos enxergando a inevitável decadência, foram tomadas providências que extrapolavam a razão, já que Seijurō e Denshichirō não davam mais as últimas palavras. Desta maneira, os remanescentes do clã - por volta de 60 indivíduos - armaram uma emboscada para encerrar de vez este episódio. Para a surpresa de todos, Musashi chegara ao pinheiro solitário de Ichijōji, local combinado para o combate, por um caminho que não fora vigiado como deveria. E o primeiro adversário 
a tomar foi Genjirō, mostrando de fato que o menino era seu objetivo. "O episódio extrapolava definições como 'trágico' ou 'brutal'. Pois não era Genjirō apenas um menino - o inimigo, sem dúvida - insignificante?" (YOSHIKAWA, 2004, p. 910). Até mesmo o narrador faz uma pequena interferência, julgando que este ato excedia os limites da razão do protagonista. Como resultado final, além de eliminar o herdeiro do clã, tombaram os outros discípulos presentes. Em meio às quase 60 mortes, somente uma despertava arrependimento em Musashi:

Naquele momento, Musashi havia matado o pequeno Genjiro sem hesitar porque tinha uma convicção: a de que não podia dar-se ao luxo de sentir pena. Mas eis que se descobria vivo depois da chacina, e se perguntava arrependido: "Por que tive de matá-Io?" (YOSHIKAWA, 2004, p. 937)

Ao decidir-se por trilhar o caminho da espada, tinha à sua frente duas opções: matar ou morrer; uma permitiria avançar ao próximo estágio e a outra findar seu objetivo, respectivamente. Por isto, não podia sentir pena a cada embate em que entrava. Mesmo em meio a uma suposta emboscada, seu adversário não era um indivíduo comum e sim uma criança de treze ou catorze anos - a mesma idade com que Musashi liquidara seu primeiro adversário e lá fora elogiado: " - É corajoso o boa-safra Take-yan!" (YOSHIKAWA, 2004, p. 37). Genjirō e Musashi (Takezō) viviam em mundos e regras diferentes, um menino amedrontado e um rebelde animalesco, sendo quase impossível equiparar os dois. Supostamente, por estar excitado com o fulgor do combate, não pôde ponderar sobre suas ações, pois um segundo de distração poderia levar à morte. Mas ao encontrar-se repousando em um templo e após questionar-se e ser questionado sobre suas ações, conclui a necessidade de seus atos, que estavam estritamente ligados à imagem do menino como símbolo máximo de uma tropa inimiga. 
Embora com a suposta conclusão deste arco contra os Yoshioka, as reações perduram pelo resto do romance. Como podemos observar na mudança de comportamento dos bonzos que haviam acolhido Musashi logo após a luta, ao descobrirem que uma criança era um dos cadáveres, começam a hostilizá-lo. "Musashi: sua fama é péssima. Fique atento quando descer daqui e voltar ao mundo dos homens, pois algo muito desagradável poderá lhe acontecer." (YOSHIKAWA, 2004, p. 943). Em geral, o protagonista é vigorosamente posto à margem por ser incompreendido em seus atos. Apesar de estar em tamanha desvantagem e seguir os ritos necessários, aparentemente determinados grupos são tomados por uma histeria afim de não aceitar nada que provenha dele. Suas atitudes são sempre julgadas por não seguirem a uniformidade da sociedade como um todo. Entretanto, suas ações podem ser compreendidas como reações a estes coletivos, podendo ser levado a realizar tais feitos inconscientemente como autodefesa. Assim como pôde observarse com a supressão de sua liberdade na vila de Miyamoto, aflorando características animalescas; agora, sendo ironizado e rechaçado pelo clã Yoshioka por não seguir a estrutura rígida do Bushidō 武士道 ${ }^{17}$ por ter e exercer o seu espírito livre de aprendizagem. Este exagero de repressão voltado a Musashi eclode por todo o romance, mas no caminho inverso, quando o coletivo excede, não há uma ocorrência em autocriticar-se, visto que tendem a justificarem ocultando os próprios erros. Mas há alguns casos em que um indivíduo componente deste coletivo reflete e pondera sobre as sucessões que o levaram a agir de tal forma, como fora o caso de Seijurō, e suas considerações não conseguiram persuadir o seu grupo.

\footnotetext{
17 "Caminho dos guerreiros", conjunto de leis que regiam o comportamento dos bushi, fundamentadas na fidelidade devida por um vassalo a seu senhor [...] Além do mais, ele devia possuir sérias qualidades morais, tais como a coragem, a abnegação total de si, a devoção filial, a generosidade, a cortesia, o espírito cavalheiresco, a frugalidade e o desprendimento. (FRÉDÉRIC, 2008, p. 146)
} 


\subsection{O SURGIMENTO DO ANTAGONISTA}

Embora houvessem grupos que cultivavam uma enorme repulsa por Musashi, seu nome começava a ganhar notoriedade por suas extraordinárias vitórias. Além de Osugi, mãe de Matahachi, que empenhavase em denegrir a imagem do protagonista por onde passava, Sasaki Kojirō, que até então não sentia-se lesado pelas histórias de Musashi, começa a desqualificá-lo em questões técnicas. Este personagem surge pouco depois do início dos problemas com o clã Yoshioka.

Kojirō, assim como Musashi, era um jovem espadachim com habilidades extraordinárias e empreendia uma viagem pelo Japão afim de aperfeiçoar-se, mas suas semelhanças acabavam com estas características. O primeiro tivera uma formação formal pelo estilo Chūjō 中条流, mas ao receber o diploma para dar continuidade ao mesmo, nega-o e prefere fundar seu próprio estilo, Ganryū 㦑流. Além disto, por contar com uma boa bagagem de conhecimento, mostrava-se extremamente arrogante e forçadamente desagradável com pessoas que não fossem de seu interesse. No momento em que constata um crescimento no reconhecimento de Musashi, não perde a oportunidade de tecer comentários com o intuito de rebaixá-lo:

[...] enfrentando sozinho os seus adversários, Musashi conseguiu que a opinião pública ficasse inteira do seu lado. Se querem porém saber a minha, digo que este último duelo nada mais foi que uma brincadeira de crianças. Musashi agiu o tempo todo com astúcia e impertinência e, no momento azado, fugiu. Reconheço que é hábil, mas de um jeito bárbaro. Ele porém está longe, muito longe, de merecer a reputação de espadachim magistral. Se querem qualificá-lo à força na categoria dos magistrais, posso dizer que é um fujão magistral, um mestre na arte da fuga: a velocidade com que foge é, sem dúvida, incomparável. (YOSHIKAWA, 2004, p. 968) 
Ao utilizar-se de sua boa eloquência e conhecimento, Kojirō, como uma testemunha ocular do último episódio contra o clã Yoshioka, expõe a sua versão a fim de persuadir pessoas que comentavam sobre o ocorrido. Apesar de ambos terem o mesmo intuito em desenvolver-se, a índole é completamente oposta. O presunçoso personagem, ao classificar o protagonista, rejeita a ideia de que ele seja considerado um espadachim, acreditando que as estratégias utilizadas não correspondem de forma alguma ao que a classe guerreira representa. Ao debochar, identificando-o como "fujão" para enaltecer suas habilidades evasivas, despreza tudo o que Musashi vem aperfeiçoando. Por outro lado, o protagonista, desde o início de sua jornada - com sua nova identidade - ao relacionar-se com outros personagens, demonstra um respeito que geralmente não é retribuído. Sua intenção de se preservar e não gerar atrito desnecessário é interpretada como ingênua e muitas vezes, dissimulada por aqueles que o incompreendem.

Após apresentar todo o seu relato e ponderações, Kojirō surpreende-se ao encontrar Musashi em outro recinto onde este pudera ouvir tudo sobre ele. Tentando contornar a situação que o próprio causara, o novo antagonista ainda tenta ludibriá-lo com pomposos elogios, porém o protagonista responde de maneira irônica:

- Quero agradecer seus bons préstimos como mediador no episódio de há dias. E também as severas críticas à minha pessoa que, deitado ali, ouvi causalmente. Deve haver diferenças entre o que eu acredito que seja a minha imagem pública e a real opinião que o público faz de mim. No entanto, são raras as oportunidades de ver-se a si próprio pelos olhos dos outros: só posso Ihe ser grato, quando penso que você me deu essa oportunidade enquanto eu dormitava. Nunca me esquecerei disso. (YOSHIKAWA, 2004, p. 971)

Diferente do jovem Takezō, o presente Musashi utilizava de um tom cordial com quaisquer pessoas com quem se relacionava. Mas nes- 
te momento sua formalidade tem a intenção de atingir Kojirō com sua própria perversidade. Desta maneira, sem que ambos fossem diretos, firmam de fato a rivalidade até então instigada pelo desenvolvimento do romance.

\subsection{NOVO DISCÍPULO PARA UM NOVO MESTRE}

Após sair de Quioto, Musashi havia se dirigido até a província de Michinoku 陸奥 $^{18} \mathrm{com}$ interesses particulares que não são explorados a fundo pelo narrador, pois acontece um salto temporal de um ano e meio na história. Antes mesmo de aproximar-se da capital, Edo, encontravase na região de Hōtengahara 法典ヶ原, na província de Shimōsa 下総 ${ }^{19}$. Neste momento ocorrerão diversas mudanças na vida do protagonista, passando por alguns processos decisivos de aprendizagem e reflexões sobre o próprio exílio. No entanto, vale ressaltar que nos seus cinco anos de peregrinação não houve declarações diretas sobre o esgotamento que uma vida solitária fustigara. Porém, Musashi estava prestes a entrar em uma nova etapa de vida e talvez necessitasse começar a cultivar desejos até então suprimidos. "[...] só ansiava por convívio humano e um pouco de comida. Estava cansado da solidão e da necessidade de exercitar-se continuamente em busca de aprimoramento." (YOSHIKAWA, 2004, p. 1163). A contínua vida andarilha escolhida pelo próprio protagonista, além de preferir estar à margem dos círculos da classe guerreira, favorecia que Musashi não tivesse um convívio diário com outras pessoas. Proporcionada pelo rigoroso esforço no auto aperfeiçoamento, a solidão, até então tida como favorável, começa a manifestar efeitos de estagnação em seu empreendimento.

\footnotetext{
${ }^{18}$ Atualmente equivalente às atuais prefeituras de Fukushima 福島, Miyagi 宮城, Iwate 岩 手 e Aomori 青森 - localizadas ao norte de Honshū 本州.

${ }^{19}$ Antiga província do Japão localizada ao norte da atual prefeitura de Chiba 千葉, leste da prefeitura de Saitama 埼玉, leste de Tóquio, e sudoeste de Ibaraki 茨城.
} 
Coincidentemente, Musashi vem a conhecer Sannosuke Iori, uma criança que viera a ficar órfão no dia anterior ao seu encontro. Toma-o como seu segundo discípulo e inicia um novo estágio de aprendizado. "A que vamos construir a partir de hoje será nossa, onde nós dois vamos viver daqui para a frente." (YOSHIKAWA, 2004, p. 1174). Ao escolher fixar-se nesta nova terra, Musashi enxerga a oportunidade de alcançar um determinado crescimento em uma região tão castigada. Mas, indagado pelo seu pupilo, que esperava uma grandiosa jornada, responde:

- Não íamos partir em jornada de aprendizagem?

- Já partimos. Eu próprio tenho ainda muito a aprender, não só a ensinar.

- Aprender o quê?

- A ser um exímio espadachim e um nobre guerreiro, está claro! Isto também significa que tenho de aprimorar-me espiritualmente. (YOSHIKAWA, 2004, p. 1175)

Musashi acredita que realizar o caminho inverso do exílio, estabelecer uma residência e dar os devidos cuidados ao seu novo discípulo fará com que ele possa desenvolver-se em outras competências também. Desta forma, a criança e o novo sítio são empregados como coeficiente para alcançar novos resultados.

O exílio [...] é fundamentalmente um estado de ser descontínuo. Os exilados estão separados das raízes, da terra natal, do passado. [...] Portanto os exilados sentem uma necessidade urgente de reconstituir suas vidas rompidas e preferem ver a si mesmos como parte de uma ideologia triunfante ou de um povo restaurado. O ponto crucial é que uma situação de exílio sem essa ideologia triunfante - criada para reagrupar uma história rompida em um novo todo - é praticamente insuportável e impossível [...] (SAID, 2003, p. 50).

Conforme Said, o exilado necessita estabelecer de forma clara quais serão os seus objetivos e principalmente os meios que serão utili- 
zados para que possa alcançar o êxito em seu caminho. Entretanto, nem todos conseguem realizar tal façanha de maneira solitária. Para isto, recorrem a associar-se a valores exemplares que apresentem determinados resultados favoráveis. Em partes, Musashi corresponde a tais ideias, mas como um indivíduo distinto, molda o seu próprio caminho.

\footnotetext{
"Se a esgrima é realmente um caminho, deve haver um modo de empregar a moralidade inerente a esse caminho para valorizar a vida", pensou. "Vou usar a esgrima não só para a evolução pessoal, mas também como meio para governar um povo e administrar um país", concluíra. (YOSHIKAWA, 2004, p. 1177)
}

Como ideologia de vida, o protagonista seguia aquilo que acreditava ser o caminho da esgrima: não o meio para vencer o próximo, mas um constante método de autodomínio para alcançar êxito em vida. Desta forma, planeja empregar sua vivência além de si, tendo agora um discípulo e um local para executar seus experimentos. Orientar o menino Iori não fora uma tarefa difícil, já que este predispunha de um engajamento prévio. O que de fato apresentou uma extraordinária dificuldade fora o local onde encontrava-se, Hōtengahara. Musashi presumia que os habitantes locais levavam uma vida miserável, mesmo sendo uma região fértil. Com o tempo aferiu os motivos e compreendeu que as enchentes eram as causadoras do sofrimento daqueles residentes.

Mesmo que trabalhasse mil vezes na terra, a cada nova enxurrada sempre retornava à estaca zero. Os habitantes, acomodados com esta recorrente situação, não perdiam a oportunidade de zombar de Musashi e Iori. "- Idiotas! Malucos! - ecoavam em seus ouvidos os gritos dos aldeões. Iori ergueu o olhar para seu mestre, imóvel ao lado [...]" (YOSHIKAWA, 2004, p. 1186) Mais uma vez, o protagonista sofre por aqueles que não enxergavam um indivíduo à frente do seu tempo. Assim como os aldeões da vila Miyamoto e os integrantes do clã Yos- 
hioka, os habitantes preferiam afrontá-lo a tentar compreendê-lo. Os três grupos por onde Musashi transita já se apresentavam como sistemas consolidados, mas com vícios que dominavam o correto discernimento. Confrontar diretamente sua vila natal e o decadente clã trouxeram grandes dificuldades para o bem-estar do protagonista. Possivelmente, adotar uma postura passiva contra o desprezo dos habitantes de Hōtengahara fora a escolha mais sábia para preservar-se.

A diferença entre esta presente vivência e as anteriores era a necessidade da vila de ter de fato um indivíduo que pudesse guiá-los. A oportunidade surge quando ocorre um ataque de bandoleiros, descrito como algo recorrente, e os numerosos habitantes nada fazem para impedir. Eis que surge Musashi e consegue socorrê-los com tamanha facilidade. A partir deste momento, todos começam a respeitá-lo e seguir suas instruções de segurança e manejo da terra.

[...] depois de exterminados os bandoleiros e restabelecida a ordem na vila, os camponeses haviam retomado a vida pacífica. Ninguém mais, no entanto, referia-se a Musashi em termos pejorativos como antigamente. Muito pelo contrário, ele era designado pelo respeitoso título de "rounin-sama de Hoten", ou "Musashi-sama".

Lavradores que antes o haviam chamado de maluco, passaram a comparecer ao seu casebre, solicitando respeitosamente a honra de ajudá-lo no trabalho de expansão daquelas terras incultas. (YOSHIKAWA, 2004, p. 1214-5).

Como descrito no trecho acima, os habitantes de Hōtengahara, ao enxergarem Musashi como um ser virtuoso, passam a respeitá-lo e tomam suas palavras como benéficas para a prosperidade da vila. Até então a única instrução direta viera do pai, possivelmente gerando um bloqueio em seu íntimo na questão de mestre e aprendiz, já que seu pai fora o seu primeiro mentor. O mesmo acontece enquanto viaja pelo Japão; ele evita frequentar as academias por apresentarem uma postura 
arrogante. Entretanto, diminuir a barreira entre o protagonista e os outros foi parte essencial no seu processo de aprendizagem. Com os maus exemplos que tivera, oportunamente pôde fazer a diferença na vida dos aldeões e também na de Iori. "- Tudo isso foi o resultado do seu trabaIho, não meu. Eu apenas mostrei-lhes como externar a força que existia em vocês." (YOSHIKAWA, 2004, p. 1215) Musashi compreendera as necessidades daqueles com quem interagia e instruía-os sem a necessidade de hostilizar, ao mesmo tempo em que mantivera uma postura austera.

\subsection{DESTINO X ASPIRAÇÃO}

Após orientar aos moradores da vila de Hōtengaraha a respeito de como deveriam agir contra as adversidades humanas e naturais, Musashi, em companhia de Iori, resolvem partir rumo à capital Edo 江戸. Ao chegarem na fronteira da cidade, são interrogados por oficiais a fim de saberem as intenções da visita. "- Passei meio ano na região de Michinoku, dois anos em Hotengahara, onde me dediquei amadoristicamente à lavoura, mas cansei-me dessa vida e resolvi vir para cá." (YOSHIKAWA, 2004, p. 1218). Depois de permanecer por um longo período em um mesmo local, Musashi, possivelmente, ao alcançar seus objetivos, prefere manter-se em movimento a estabelecer um vínculo forte que poderia prendê-lo. "[...] o exilado insiste ciosamente em seu direito de se recusar a pertencer a outro lugar." (SAID, 2003, p. 55). Conforme Said, o indivíduo em exílio não se sente na obrigação de permanecer em um determinado grupo, preferindo manter-se distanciado ao ponto de preservar sua liberdade como indivíduo, obtida com muito sacrifício desde que ocorre o rompimento inaugural. Para o protagonista, permanecer por mais de dois anos em um único local nada mais foi que uma etapa de seu aprendizado. Desde que Musashi partira de sua terra natal, agarrara cada oportunidade que surgira à sua frente, 
mas compreendia a necessidade de permanecer em movimento para que fossem proporcionadas novas experiências engrandecedoras.

Para Musashi, ter sido como um mestre aos aldeões de Hōtengaraha, sem que houvesse uma pretensão prévia, proporcionou-Ihe uma maior visibilidade a indivíduos de uma condição social superior. Um que havia despertado um grande interesse por Musashi fora Nagaoka Sado, vassalo e secretário Hosokawa Tadaoki - famoso general e suserano do castelo Kokura 小倉, em Buzen 豊前 ${ }^{20}$.

\begin{abstract}
Mais exatamente, seus pensamentos voltavam-se para um outro homem, por quem se interessara mais de ano e meio atrás, mas com quem não conseguira encontrar-se, premido como esteve pelas obrigações rotineiras.

O homem que tanto interessara Sado era um rounin que se dedicava a expandir as terras áridas de Hotengahara, a leste do rio Sumidagawa. Seu nome: Miyamoto Musashi. (YOSHIKAWA, 2004, p. 1209)
\end{abstract}

Por ter executado uma transformação tão notável em pessoas com uma debilitada perspectiva, além de desvendar os problemas ambientais da região, Musashi impressionou Sado por ser um indivíduo com qualidades múltiplas.

Além disto, no meio da classe guerreira e das pessoas ligadas a este grupo, começavam a ecoar a popularidade de Musashi, que havia há pouco chegado na capital Edo. Tendo um encontro com Zushino Kōsuke, polidor de espadas e discípulo de Hon'ami Kōetsu, declara: "Estarei eu por acaso na presença de Miyamoto Musashi-sama, o espadachim cuja habilidade se tornou conhecida no país inteiro pelo episódio em torno do pinheiro solitário, em Ichijoji?" (YOSHIKAWA, 2004, p. 1236). Conforme Kōsuke manifestou, Musashi começou a ser reconhe-

\footnotetext{
${ }^{20}$ Antiga denominação de uma área constituída pela região oriental da atual província Fukuoka e por parte da região setentrional da província de Ōita, em Kyūshū.
} 
cido pelo Japão após o episódio contra o clã Yoshioka, que havia tomado grandiosa proporção.

Outro que havia se impressionado com a figura do protagonista fora Obata Kambei Kagenori - mestre da academia Obata -, que mesmo debilitado pela saúde foi instrutor de artes marciais de Tokugawa Hidetada - filho do xogum Tokugawa Ieyasu.

- Não o conheço nem nunca o vi antes. Digo-lhe no entanto, meu filho, que este velho já teve a oportunidade de se avistar com muitos homens respeitáveis nos longos anos de sua vida, tanto em campos de batalha como no cotidiano, mas poucos, muito poucos entre eles eram autênticos bushi. Algo, porém, chamou-me a atenção nesse que acaba de se afastar. Quero vê-lo! Quero a todo custo avistar-me com esse Miyamoto Musashi e trocar algumas palavras com ele.

$[\ldots]$

- Esse samurai... manteve-se em guarda até contra mim, um velho enfermo! $E$ isso é admirável. (YOSHIKAWA, 2004, p. 1303-4)

Sem que houvesse um encontro direto entre este senhor e Musashi, mesmo estando na mesma residência, Obata pôde reconhecer a sua maestria. Podemos observar, por meio destes relatos, que o protagonista havia apresentado um grande crescimento durante a sua jornada. Para Sado e Kōsuke, as constatações foram construídas por intermédio de terceiros, e para Obata, concluíra com base na sua formação guerreira.

Por outro lado, sua reputação também sofreu por injúrias criadas por Osugi e Kojirō, além da academia de marginais Hangawara - assim como é descrita no romance -, onde ambos cultivaram uma relação bastante próxima.

- É um desavergonhado, o homem que mais denegriu o código de honra do bushi. E se os Yoshioka de Kyoto foram realmente 
derrotados por ele, ou eram todos incapazes, ou Musashi, o perito em fugas, escapuliu espertamente e construiu falsa reputação em cima do episódio.

A fama era, portanto negativa, mas Musashi não encontrou ninguém que depusesse a seu favor porque os capangas de Hangawara tinham logo em seguida espalhado boatos maldosos por toda a redondeza e erguido placas em cada esquina da cidade, anunciando em linguagem grosseira [...] (YOSHIKAWA, 2004, p. 1315)

Há um assíduo esforço em denegrir a imagem de Musashi; os capangas de Hangawara, a mando de Osugi e Kojirō, espalhavam inverdades por todos os cantos da cidade. Ao que tudo indica, numa época em que os meios de comunicação não existiam como os de hoje, quem espalhasse algo com tamanha insistência seria capaz de criar uma verdade por trás de uma mentira. Desta forma, a opinião popular em relação ao protagonista foi moldada por este grupo que ambicionava marginalizá-lo cada vez mais. Segundo o narrador (2004, p. 1323), mesmo Musashi tendo apresentado um talento sem igual, o ser humano mantinha o costume de julgar qualquer que fosse a pessoa, ainda mais um sujeito oriundo de uma posição inferior. Mesmo que houvesse exemplos de personalidades que ascenderam a partir de uma condição improvável, assim como Toyotomi Hideyoshi 豊臣秀吉 ${ }^{21}$, ele não era levado em consideração.

Enquanto a reputação de Musashi ia sendo injuriada, ele tivera uma grata surpresa ao encontrar-se com Sōhō Takuan, Hōjō Ujikatsu e Yagyū Munenori: o primeiro, o monge e velho conhecido dele; o segundo pai de Hōjō Shinzo, este que havia sido salvo por Musashi após ferirse contra Kojirō; e por último, o descendente de uma das mais célebres famílias que serviam ao xogum Tokugawa Ieyasu. Os três, que circula-

\footnotetext{
${ }^{21}$ De um humilde lavrador à Daimiō do Período Sengoku (1467-1573) que unificou o Japão, dando início ao Período Azuchi-Momoyama (1573-1603).
} 
vam pelas camadas mais nobres da aristocracia, decidiram indicar o protagonista à casa xogunal, no cargo de instrutor de artes marciais.

Mesmo sendo uma honra ser indicado a servir o xogum, Musashi carregava em seu íntimo um sentimento de insatisfação, uma vez que nesta ocasião os rumos de sua vida não estavam sendo tomados de maneira natural, como até então havia trilhado.

\footnotetext{
"Mas se aceito agora o cargo de instrutor da casa xogunal e me considero realizado, minha carreira terá terminado aqui e agora, sem ter visto grandes Progressos."

Pela estrada banhada por luminosos raios matinais seguia Musashi formalmente vestido, cavalgando um magnífico cavalo ricamente ajaezado, passo a passo aproximando-se do portal da fama. Em seu peito, porém, havia uma vaga insatisfação. (YOSHIKAWA, 2004, 1523-4)
}

A preocupação de Musashi estava na estagnação do seu aprendizado se viesse a ocupar um cargo. Apesar de ter diversos benefícios em servir a casa xogunal, deveria seguir o rígido protocolo e isto colocaria em risco a liberdade de que tanto gozava. E esta era a principal característica da sua formação.

É mais comum a pressão sobre o exilado para entrar - em partidos, movimentos nacionais ou no Estado. O exilado recebe a oferta de um novo conjunto de afiliações e estabelece novas lealdades. Mas há também uma perda - de perspectiva crítica, de reserva intelectual, de coragem moral. (SAID, 2003, p. 57)

De acordo com Said, o exilado que se sobressai em sua trajetória, muitas vezes, é sondado a fazer parte de um determinado grupo por ter qualidades que são almejadas no desenvolvimento coletivo. Entretanto, o indivíduo que cultiva a liberdade oriunda da individualidade, ao associar-se, tende a perder esta característica tão importante na auto formação pela obrigatoriedade de seguir princípios já estabelecidos. E 
não é diferente com Musashi, que se tornando um vassalo do xogum, deveria abdicar de toda as suas ambições em prol da nação. Como não considerava que houvesse alcançado seus objetivos em sua trajetória, enxerga nessa oportunidade um estrangulamento de sua natureza. Até então, todo o seu desenvolvimento fora construído por meio da individualidade que tanto defendia, e submeter-se a uma autoridade seria o fim da sua originalidade. "[...] o exilado pode fazer do exílio um fetiche, uma prática que o distancie de quaisquer conexões e compromissos. Viver como se tudo a sua volta fosse temporário e talvez trivial [...]" (SAID, 2003, p. 57) Para Said, aquele que não tem interesse em associar-se a um grupo para perpetuar sua liberdade prefere levar uma vida efêmera a subordinar-se. Este é exatamente o caso de Musashi, um nômade que subsiste de maneira extremamente simples, somente com o que a natureza lhe provém, sem posses de bens e muitas vezes pernoitando sob as estrelas. Seu único comprometimento é com o caminho da espada, de tal forma anulando tudo que poderia lhe abstrair para se tornar um exímio nesta arte.

Para a surpresa do protagonista, sua contratação é negada a mando do xogum. Além disso, tudo indicava que as inverdades propagadas por Osugi, Kojirō e o grupo Hangawara, possivelmente haviam surtido efeito e influenciado na decisão de Tokugawa.

[...] usado intencionalmente palavras como maledicências da plebe, elogios e ataques ocultos, percebeu Musashi. "Você não tem de Ihes dar resposta, mas de algum modo, deixe registrada a inabalável conviç̧ão de um bushi em sua própria integridade!", parecia-lhe ouvir dizer o homem nas entrelinhas. (YOSHIKAWA, 2004, 1526)

Musashi já demonstrava superioridade por estar alheio as injúrias. E a casa xogunal, como aprovação de seu caráter, instiga-o a manifestar de alguma forma o resultado da sua formação. Este o faz com 
excelência, realizando uma pintura em um biombo. E ao partir, constatam: "- Que lástima! O tigre retornou à selva!" (YOSHIKAWA, 2004, p. 1528). Esta frase define muito bem quem era Musashi, um ser altamente refinado mas indomável, não podendo ser mantido trancafiado, e sim livre na natureza. Um animal sublime contemplado em seu habitat. $O$ isolamento do protagonista só exercia efeitos benéficos à sua personalidade. Mesmo não seguindo nenhum padrão de educação, sua originalidade é sem igual.

\subsection{FINAL SEM FIM}

Após sair da audiência na casa xogunal, Musashi decide partir novamente, mas agora sem a companhia de seu discípulo. "[...] pretendo embrenhar-me uma vez mais nas montanhas, longe de tudo e de todos." (YOSHIKAWA, 2004, p. 1530). Sua necessidade em isolar-se está estritamente ligada à imersão de autodescobrimento, o princípio de sua criatividade. Na última parte do romance, o protagonista desaparece das páginas e dá espaço ao desenrolar de outros personagens, possivelmente devido ao fato de Yoshikawa Eiji não ter registros concretos de toda a trajetória de Miyamoto Musashi (real), e isto é refletido no romance. "Não é nada fácil levantar suas pegadas, pois Musashi surgia de súbito num ponto para depois desaparecer casualmente, volátil como um floco de nuvem em torno de um pico." (YOSHIKAWA, 2004, p. 1649). Para ressaltar este trecho, Luiz Kobayashi (2010, p. 209) pontua sobre a escassez de informações e a existência de registros incoerentes e inexatos. Desta forma, ao exilar-se, alimenta e estimula seu espírito livre para novas criações.

Para finalizar o romance, Yoshikawa coloca frente a frente Miyamoto Musashi e Sasaki Kojirō, no mais importante episódio do nosso herói. "- Este será um duelo entre dois hábeis espadachins: um, que possui aptidão natural e é arrogante; o outro, que sabe de suas limita- 
ções e se empenhou em polir a própria habilidade." (YOSHIKAWA, 2004, p. 1719). Ambos eram conhecidos como extraordinários e desenvolvedores de seus próprios estilos de luta, mas as personalidades eram extremamente opostas. Além disto, como já bem conhecemos, o protagonista sempre teve uma postura mais contida e educada. Já seu antagonista preferia estar às luzes dos holofotes, portando-se de maneira presunçosa com um toque de desmerecimento.

Ao chegar no dia 13 de abril de 1612, data do emblemático confronto, Musashi atrasa-se, como já havia feito em episódios anteriores, a fim de desestabilizar seu adversário. Por fim, o embate finaliza com a vitória de Musashi, o qual novamente desaparece de maneira repentina.

Não existe nenhum relato dando conta de que os discípulos de Ganryu, emboscados na ilha Hikojima, tivessem se confrontado com Musashi para vingar a morte do admirado mestre.

Enquanto viver, amor e ódio farão parte do ser humano.

O tempo passa, mas os sentimentos são como ondas a vibrar continuamente, ora altas ora baixas. Enquanto Musashi viveu, pessoas que não o apreciavam continuaram a criticar-lhe o comportamento daquele dia. (YOSHIKAWA, 2004, p. 1808)

Independente da habilidade que Musashi possuía, por ser um indivíduo totalmente oposto às características esperadas de um bushi, é sempre desprezado por aqueles que não acreditam em sua arte, uma originalidade sem igual. Contudo, esta maneira de exilar é compreendida como favorável ao protagonista, como recurso à sua formação. 


\section{CAPÍTULO 3. OS CAMINHOS DE UMA FORMAÇÃO}

[...] o protagonista dos Bildungsromane alcança, segundo as definições tradicionais do gênero, um equilíbrio no fim de sua trajetória, um misto de "harmonia com liberdade" [...] (MAAS, 2000, p. 72)

\subsection{FORMAÇÃO COMO GÊNERO}

Após termos um panorama do romance como um todo pela perspectiva do exílio no capítulo anterior, agora iremos percorrer o caminho da formação de Miyamoto Musashi. O intuito é examinar partes da obra que contenham os traços do aperfeiçoamento do protagonista, quando surgiu e quais foram os aprendizados.

Ao pensarmos em determinadas personalidades memoráveis na história mundial, temos a descrição destes indivíduos de forma conclusa e cristalizada, havendo a possibilidade de não se dar a devida importância a toda trajetória até o momento em que tal personalidade passa a ser conhecida por seus feitos extraordinários. Esta composição já finalizada pode ser também encontrada no campo literário. Um exemplo pode ser a Odisseia, obra épica de Homero, onde embarcamos nas aventuras de Odisseu regadas a inúmeros perigos que ameaçam sua sobrevivência. Entretanto, a obra se constrói em uma sucessão de acontecimentos sem o acompanhamento da evolução de seu protagonista, pois esta evolução já se encontra alcançada dentro da personalidade do herói e o que resta é a resolução, com a já esperada maestria, dos problemas iminentes.

Em oposição a esta proposta do indivíduo pré-estabelecido, há obras que prezam por acompanhar o desenvolvimento do seu protagonista por todo o caminho percorrido até alcançar a sua imagem conclusa, já que a peregrinação do protagonista é constituída por elementos essenciais à formação de sua futura identidade. O surgimento do inte- 
resse em romper uma tradição, que beira uma imposição, é primordial no ímpeto do herói de buscar algo realmente seu, para que consiga se enquadrar onde antes não Ihe era possível ou permitido. Desta forma, o mundo se abre aos seus olhos e diversas experiências podem ser vivenciadas no intuito de alcançar uma determinada formação, dependendo única e exclusivamente do esforço empregado pelo indivíduo.

Para apresentar o caminho de evolução do protagonista frente ao mundo, Wolfang von Goethe (1749-1832) escreve o romance Os anos de aprendizado de Wilhelm Meister (1795-1796), considerado um paradigma no gênero de narrativa alemã denominado Bildungsroman (Romance de Formação). Este termo acompanhara os acontecimentos da Alemanha do final do século XVIII, dos quais era

[...] contemporâneo do momento de transição entre a economia feudal latifundiária e o prenúncio da fase econômica e política em que os ideais e privilégios da aristocracia serão dissolvidos em meio ao tecnicismo e ao cientificismo burguês" (MAAS, 2000, p. 71)

Era, portanto, uma repercussão da divergência entre o indivíduo e o mundo. Para que possamos compreender as dimensões que cabem ao Romance de Formação, precisamos perpassar as engrenagens de seu surgimento até a sua consolidação como gênero literário. De acordo com a perspectiva morfológica, o termo Bildungsroman se deu por meio da justaposição de dois radicais, Bildungs (formação) e Roman (romance), compondo assim um patrimônio institucional sócio-literário, resultante do aperfeiçoamento almejado pelo jovem de origem burguesa (como indivíduo, mas também como classe), que por sua vez convergiu com a elevação do gênero romance, passando a não mais carregar o estigma de uma literatura banal.

As circunstâncias de origem do Bildungsroman são contemporâneas desse esforço pela atribuição de um caráter nacional à lite- 
ratura de expressão alemã. Trata-se de uma forma literária de cunho eminentemente realista, com raízes fortemente vincadas nas circunstâncias históricas, culturais e literárias dos últimos trinta anos do século XVIII europeu. (MAAS, 2000, p. 13)

Ao sustentar esta concepção, a crítica passou a compreender o Romance de Formação como um meio fundamentalmente alemão, o qual exprime intensamente o seu próprio espírito a ponto de se firmar dentro da sua literatura, posteriormente sendo adotado por outras nações que passavam por um estado de mudanças.

\subsection{MUSASHI COMO ROMANCE DE FORMAÇÃO}

A partir dos imprecisos registros acerca de Miyamoto Musashi, Yoshikawa Eiji concebe para o campo literário uma obra com tamanha profundidade, conforme Wilson (2006, p. 226), que se tornou incapaz de ser retratada em obras teatrais por motivos técnicos. Ao estender-se por 1800 páginas, acompanha a trajetória do protagonista numa imersão de autodescobrimento. Desta forma, podemos observar elementos que atuarão como formadores em sua vida.

O romance de Yoshikawa caminha no sentido oposto ao de tantas obras que se dedicam exclusivamente a narrar as grandiosidades de heróis com imagens imutáveis. Nestas histórias ocorre uma progressão ao movimentar o espaço do herói aos seus pés, não alcançando um desenvolvimento, uma vez que o protagonista começa e termina a sua aventura de maneira homogênea. Desta forma, o romance de formação tem como maior interesse quebrar esta estabilidade do herói.

Em contraposição à unidade estatística, aqui se fornece a unidade dinâmica da imagem da personagem. O próprio herói e seu caráter se tornam uma grande variável na fórmula desse romance. A mudança do próprio herói ganha significado de enredo e em face disso reassimila-se na raiz e reconstrói-se todo 
o enredo do romance. O tempo se interioriza no homem, passa a integrar a sua própria imagem, modificando substancialmente o significado de todos os momentos do seu destino e da sua vida. Esse tipo de romance pode ser designado no sentido mais amplo como romance de formação do homem. (BAKHTIN, 2011, p. 219-20, grifo do autor)

Segundo Bakhtin, expõem-se então a imagem de um herói oposto a um indivíduo já concluso, e o movimento de mudar o seu íntimo, que fazem o enredo deste tipo de romance, compondo a construção de uma trajetória desencadeada por etapas significativas dentro de espaços diversificados. Porém, para que ocorra uma interiorização de todos esses ensinamentos absorvidos, é imprescindível que o protagonista esteja integralizado com um tempo que seja seu, efetivando assim uma eficaz assimilação de suas experiências.

A formação do indivíduo sistematizada por Jürgen Jacobs (1989, apud MAAS, 2000, p. 62) é compreendida como uma obra cujo núcleo da história seja a vida de um jovem protagonista, conduzido por desagrados até o seu equilíbrio com o mundo. Este último é representado de forma irônica. Para que isso ocorra, o processo dar-se-á com o contato de experiências diversas, como: rompimento familiar, presença de mentores, proximidade com diferentes círculos sociais e sua elevação a uma pessoa pública.

Desta maneira, o herói de Yoshikawa, ao realizar sua jornada aos confins do Japão, terá vivências capazes de transformá-lo em um indivíduo totalmente contrastante ao que era em sua partida.

Musashi é instruído por uma série de situações e objetos improváveis encontrados em suas viagens: a concentração total de um ceramista, os comentários cáusticos de um polidor de espadas a respeito da alma dos samurais, o caule de uma peônia enviada a Yoshioka por Yagyu Sekishusai, e mesmo sua escavação da terra. O mais dramático, porém, é a instrução sem pala- 
vras que ele recebe de um monge zen-budista chamado Gudo. (WILSON, 2006, p. 223-4)

De acordo com Wilson, Musashi é capaz de distinguir e absorver ensinamentos em inesperadas situações. Esta característica mostra-se como um fator determinante entre ele e outros personagens presentes na obra, no que diz respeito ao sucesso e fracasso. Todavia, o protagonista não apresenta este tipo de excepcionalidade desde o início do romance. Para que isto ocorresse ele necessitava de um conflito, ou meIhor, um agente que o despertasse.

\subsection{PRIMEIROS PASSOS PARA A FORMAÇÃO}

Como foi apresentado no capítulo anterior, o protagonista da obra chamava-se Shinmen Takezō e depois passou a ser conhecido como Miyamoto Musashi; fora considerado um jovem problemático por seu pai e conterrâneos.

Takezo tomou conhecimento da doença e posterior morte da mãe. De criança introvertida e sombria, repentinamente Takezo tornou-se violento, incontrolável. Até mesmo Munisai por fim calou-se, pois se erguia um bastão com a intenção de castigá-lo, Takezo o enfrentava empunhando um bordão. Chefiava o bando de desordeiros da localidade [...] (YOSHIKAWA, 2004, p. 37)

Com a perda da mãe, o jovem protagonista transfigurou-se em um indivíduo violento, sem que houvesse alguém que conseguisse frear suas atitudes. Seus atos rebeldes cresciam conforme a repressão daqueles que o cercavam era exercida. A partir destes fatos, de acordo com Jacobs (1989, apud MAAS, 2000, p. 62), começamos a observar as primeiras disposições de um sujeito que será levado a percorrer um caminho de formação. A primeira, que podemos considerar como estopim, fora a solidão sentida no meio familiar, progredindo para o seu iso- 
lamento dentro da comunidade em que vivia. Depois, cansado daqueles que estavam à sua volta, planeja a sua partida para a batalha de Sekigahara.

Essa partida para a guerra [...] mostrava o início de uma revolução em sua personalidade: em algum canto começava a ganhar corpo a vontade de se humanizar. No momento, porém, havia perdido o rumo outra vez. A realidade era sombria. (YOSHIKAWA, 2004, p. 37)

Takezō acreditava na potencialidade que a guerra oferecia para que pudesse alcançar grandiosos resultados e assim exibir para sua vila o valor que possuía. Porém, nada corre conforme o planejado; sobrevive, mas sem nenhuma perspectiva de prosperidade. 0 equívoco em sua avaliação é considerado outra disposição sintetizada por Jacobs (1989, apud MAAS, 2000, p. 62), vindo a ser corrigida ao longo da sua trajetória de desenvolvimento. Em Musashi, esta correção inicia-se quando o protagonista é enfrentado pelo monge Takuan, e este se torna uma espécie de mentor para o jovem. A presença de uma personagem com a função de orientar é primordial no conceito proposto por Jacobs (1989, apud MAAS, 2000, p. 62) para a formação do herói.

- O mesmo se dá com a sua coragem: todas as suas ações, até agora, demonstraram temeridade, uma falsa coragem que deriva da ignorância. Não são atos de um ser humano, nada têm a ver com a verdadeira força de um bushi. O homem, o verdadeiro bravo, teme o que tem de ser temido, poupa e resguarda a vida - esta pérola preciosa - e procura morrer por uma causa digna. Percebe agora o que há de tão lamentável em tudo isso? Você veio ao mundo possuindo força física e firmeza de caráter, mas é inculto - aprendeu apenas o lado sombrio da arte guerreira, não procurou cultivar a sabedoria e a virtude. "Aperfeiçoar-se no duplo caminho das letras e das armas" - conhece a expressão? Mas que significa "duplo caminho"? Sem dúvida não significa que dois são os caminhos a serem percorridos em bus- 
ca do aperfeiçoamento; significa, isto sim, que os dois caminhos, das letras e das armas, estão juntos e perfazem um único caminho. Compreendeu, Takezo? (YOSHIKAWA, 2004, p. 115)

Estas palavras expressas por Takuan tinham como objetivo iluminar a consciência de Takezō, em todas as escolhas que o protagonista havia tomado até então. Todos os seus atributos estavam sendo utilizados de maneira incorreta, compreendendo que em vez de levá-lo para frente, rumo ao progresso, o faziam regredir. Desta forma, o choque com aqueles que não o compreendiam perpetuaria até o fim de sua vida. A orientação do monge para interromper esta condição cármica, que perdurava desde a infância, era buscar o aperfeiçoamento pessoal nos caminhos das armas e das letras. Possivelmente, o caminho das armas deveria ser seguido conforme as principais virtudes do Bushidō: justiça ( $g i$ 義), coragem ( $y \bar{u}$ 勇), benevolência (jin 仁), educação (rei 礼), sinceridade (makoto 誠), honra (meiyo 誉) e lealdade (chūgi 忠). Quanto à das letras, Takuan exemplifica:

- Leia tudo o que Ihe for possível. Diz-se que certo renomado monge chinês encerrava-se periodicamente numa enorme biblioteca e lia milhares de livros. E a cada vez que de lá saía, diz a lenda, aos poucos seus olhos espirituais se abriam. Quanto a você, encerrado neste escuro recinto, considere-se dentro do ventre materno, preparando-se para o nascimento. Aos olhos da carne, este recinto nada mais é que um escuro quarto selado. No entanto, olhe com atenção e medite: a sala está repleta de luz, luz que todos os tipos de sábios da China e do Japão ofereceram à civilização. Tanto poderá viver enclausurado num escuro quarto selado, ou passar os dias numa sala cheia de luz - a escolha é sua e cabe ao seu espírito decidir. (YOSHIKAWA, 2004, p. 146)

Após estas palavras, Takezō permaneceu encarcerado durante três anos em um aposento da torre do castelo do suserano Ikeda Teru- 
masa, para que pudesse instruir-se e enfim alcançar a luz, conforme prevera. É possível compreender que as letras seriam todos os ensinamentos, literários ou não, acumulados por centena de anos. Portanto, poderia absorver variadas lições e experiências de vidas anteriores à sua. Assim, alcançaria a erudição pelas letras, ou como o próprio Takuan dissera, abriria os olhos espirituais, permitindo-lhe que trilhasse, por novos caminhos prósperos, a sua aptidão. Além disto, possibilitaria um senso crítico aos futuros desafios que viria a enfrentar, sabendo ministrá-los da melhor maneira possível.

Ao ser liberado, torna-se um novo homem, Miyamoto Musashi, e as primeiras mudanças em seu caráter já estavam implementadas. Antes tratava as pessoas de maneira grosseira e com arrogância; agora a polidez fazia parte do seu linguajar. Terumasa, impressionado com a mudança drástica de comportamento, indaga-o sobre quais seriam os seus planos. "- E então, é tua intenção voltar à vila Miyamoto e terminar teus dias como um goushi?" (YOSHIKAWA, 2004, p. 147). O protagonista não desejava permanecer preso a sua classe de origem, conhecida como gōshi 郷 $\pm^{22}$. Abdica, de tal maneira, de um direito seu, o de permanecer incluído à casta. No período Edo (1603-1867), as classes sociais eram estruturadas da seguinte maneira: samurai, camponês, artesão e comerciante; além disto, seguiam de maneira decrescente de grau de importância e havia algumas variáveis - como a descrita acima - e as excluídas da sociedade - burakumin 部落民 ${ }^{23}$ e hinin 非人 ${ }^{24}$.

Em teoria, a classe era determinada pelo nascimento e a mudança de classe era difícil, embora, na prática, não fosse impos-

\footnotetext{
${ }^{22}$ Esta classe correspondia aproximadamente à dos fidalgos rurais na camada social, estando entre os bushi e os camponeses. Possuía alguns privilégios da sua classe superior, mas regularmente exercia trabalhos com a agricultura.

${ }^{23}$ Era a casta mais baixa na hierarquia social. Eles trabalhavam em funções consideradas impuras, como executores de criminosos, fabricantes de couro, açougueiros, limpadores de rua e coveiros.

${ }^{24} \mathrm{Na}$ época de Edo, eles não tinham o direito de exercer nenhuma profissão e eram reduzidos à mendicância. Assemelha-se aos burakumin em questão de profissão e exílio.
} 
sível, ao contrário do que em geral se crê. Uma das separações mais importantes era a que existia entre os samurais e os não samurai. (HENSHALL, 2008, p. 81)

Como Henshall explicita, a mobilidade social não era algo tão comum de ser realizado, sendo um dos fatores de controle implantado pelo xogunato. Com as dificuldades exercidas, indivíduos acomodavamse e não demonstravam pretensão de modificar suas posições. Desta forma, a formação que cada pessoa deveria ter preservava-se junto à estabilidade social.

[...] o conceito de formação encontra-se intimamente ligado à articulação da sociedade em classes. Em nome da funcionalidade social, cada cidadão deveria receber a formação que o habilitasse da melhor maneira para o desempenho de sua função junto à coletividade. (MAAS, 2000, p. 32)

Assim, a formação determinada a cada classe social, conforme Maas, resulta na diminuição na individualidade em benefício à coletividade, característica evidente na cultura japonesa. Entretanto, Musashi não desejava privar-se de sua independência, compreendendo que esta era a força motriz para sua criatividade. "Musashi, por seu lado, preparava-se para dar o primeiro passo no árduo caminho de adestramento e disciplina ascética, rumo à sua formação pessoal e guerreira." (YOSHIKAWA, 2004, p. 148-9). O protagonista ambicionava seguir em busca de uma formação, mas não aquela comum a todos, e também não demonstrava querer ascender à classe dos samurais, mas sim transcender este rígido sistema. Ele segue inicialmente pelo caminho da espada e depois, com o desenvolvimento do romance, ao entrar em contato com outras personalidades de diferentes tipos, encontra nas artes e administração os elementos para uma formação universal. 


\subsection{AS DIFICULDADES PARA UMA FORMAÇÃO GUERREIRA}

Ao partir de sua vila, Musashi estava decidido a seguir uma viagem de auto aperfeiçoamento como shugyōsha. Seu objetivo era se embater com indivíduos de diversos estilos, para enfim poder estabelecer sua própria escola ou estilo. Porém, este caminho não permitia que tal sujeito exprimisse qualquer indício de hesitação frente a um adversário, pois a possibilidade de morte era real.

O primeiro local a ser visitado por Musashi fora a Academia Yoshioka, estabelecida na cidade de Quioto. O estilo de esgrima ali praticado, mesmo que fosse possível observar sinais de decadência, tinha certa reputação por ter sido instruído ao clã xogunal no período Muromachi 室町 (1338-1573).

No que diz respeito à formação prévia pelo caminho das armas, Musashi responde de tal maneira quando é questionado por membros do clã Yoshioka:

- Aprendi, em criança, a manejar o jitte com meu pai. Depois disso, obtive orientação de alguns poucos guerreiros que passaram por minha vila; aos 17 anos, parti de minha terra e, dos 18 aos 20 anos, por motivos que não vêm ao caso, devotei-me apenas ao estudo das letras; durante todo o ano passado encerrei-me sozinho nas montanhas e me apliquei, tendo por mestres as árvores e os espíritos das montanhas. Assim sendo, não tenho ainda mestre ou um estilo estabelecido. Pretendo, no futuro, seguir os passos do lendário Kiichi Hogen e, adotando como modelo o espírito do famoso estilo Kyohachi da escola Yoshioka, almejo, embora consciente de minha inexperiência, empenharme para criar, assim como o fez mestre Kenpo, um estilo próprio: o estilo Miyamoto de esgrima. (YOSHIKAWA, 2004, p. 185-6)

Os conhecimentos que possuía foram passados por seu pai na infância e por outros guerreiros; depois disto, utilizava-se somente de sua 
força excepcional, sem que houvesse técnica para derrotar seus adversários. Agora Musashi, ao iniciar-se no caminho do desenvolvimento pela espada, mesmo tendo alguns exemplos que respeita, demonstra que sua ambição não se inclinará para uma formação tradicional. Ou seja, a obtenção de conhecimento não ocorrerá pela relação de mestre e discípulo. A partir da sua percepção de diferentes estilos que virá a conhecer, comporá o seu próprio.

No entanto, ao adentrar o mundo das artes marciais, especificamente das espadas, o protagonista sofrerá desprezo por adotar um posicionamento excêntrico. Recapitulando o que foi dito anteriormente por Henshall (2008, p. 81), no que diz respeito à estratificação das classes sociais e principalmente a distinção entre os samurais e os não samurais, há uma falta de cumplicidade entre aqueles que já estavam inseridos nesta elevada classe e aqueles que desejavam ascendê-la.

Assim, os membros da academia Yoshioka começam a demonstrar um enorme desprezo contra o protagonista, inicialmente por apresentar-se maltrapido, e depois intensificado por admitir que pretendia fundar um estilo próprio. Subestimando-o, alguém sugere que the perguntasse o que faria com o seu corpo, acreditando que a vitória sobre Musashi era certa.

Este momento representa a opinião dos integrantes da academia Yoshioka, reforçando a ideia da distinção entre classes, principalmente quando um indivíduo origina-se de uma condição inferior. Musashi descende de uma família de gōshi, mas neste momento denomina-se um rōnin 浪人 ${ }^{25}$. Consequentemente, a possibilidade de adentrar efetivamente no mundo das espadas mostra-se restrita a pessoas desta classe, na maioria das vezes.

A consciência de que as possibilidades de ampliação de horizontes reservadas à classe a qual pertence são ínfimas [...] e con-

\footnotetext{
25 Nome empregue aos guerreiros e samurai que ficaram sem mestre ou senhor por causa da conquista ou da desapropriação de seus territórios.
} 
trapô-lo às possibilidades reservadas à aristocracia. Delineia-se, portanto, a consciência de uma sociedade dividida em classes cujos limites inflexíveis constrangem [...] a seu próprio círculo de atuação, sem que se vislumbre a possibilidade de ultrapassálo. (MAAS, 2000, 34-5)

De acordo com Maas, existe uma escassez de oportunidades disponibilizada às classes que não integram as mais elevadas, e este cenário é proporcionado pela estratificação social de cada sociedade, delimitando a cada indivíduo a permissividade em sua existência. Desta forma, o romance de formação tem como ímpeto apresentar um personagem que, insatisfeito com essas limitações, ambiciona converter esta rigidez da formação especializada - direcionada a cada classe - em uma formação universal. Com isto, o desenvolvimento de Musashi torna-se muito mais amplo e mesmo que o seu aperfeiçoamento como guerreiro seja o objetivo principal, este será fortemente influenciado por outras competências.

Como vimos no capítulo anterior, o protagonista vivenciará uma trajetória de exílio por não seguir os costumes vigentes da época. Mas isto não será uma adversidade que impedirá Musashi, e sim um combustível para seguir adiante.

\subsection{FORMAÇÃO UNIVERSAL}

Enquanto Musashi avança em sua formação universal, é interessante notar que em todas as especialidades com que ele entra em contato, o seu desenvolvimento é apresentado de maneira autodidata. Entretanto, conforme Jacobs (MAAS, 2000, p.62), ao transitar pelas esferas da sociedade, haverá a atuação de mentores, mesmo que não vejamos os ensinamentos de maneira tão explícita.

Yoshikawa, por sua vez, não dá a Musashi instrutores de esgrima, mas lhe fornece instrutores de vida, ao longo do romance. 
Esses instrutores, além disso, são percebidos como absolutamente necessários para a maturidade da arte de Musashi. (WILSON, 2006, p. 220)

Cada personagem "ilustre" que Yoshikawa insere durante o romance, torna-se uma peça importante para o desenvolvimento como um todo do protagonista. Assim, "[...] os acontecimentos e personalidades que, intervindo em sua trajetória, configuram e determinaram gostos, tendências e comportamentos." (MAAS, 2000, p. 66). Além das personalidades presentes na obra, ocorrem episódios que contribuem para uma revolução em sua imagem. No fim, após todo este processo, numa convergência de conhecimentos, nos deparamos com um personagem sublime - se comparado ao seu início.

Mas até chegarmos a este ponto,

[...] o conceito de Bildung como formação universal é o que regula e dirige a trajetória do protagonista [...] buscando sempre possibilidades de desenvolver suas potencialidades latentes em todas as direções. [...] na medida em que não forma o indivíduo para profissões específicas, mas sim para uma atuação universal. (MAAS, 2000, p. 38)

A partir do momento em que Musashi interioriza uma formação universal, em toda e qualquer oportunidade que houver em sua vida, mesmo que pareça banal a outros personagens - ou até mesmo para o leitor -, temos a imagem do protagonista extraindo um novo aprendizado. Além disso, é necessário levar em contar duas características importantes, apresentadas por Wilson (2006, p. 219), para compreendermos como ocorre seu desenvolvimento: determinação e entendimento. A primeira está presente na ininterrupta busca de conhecimento, e a segunda em como ele o processa, além de conseguir aplicá-lo.

[...] em Musashi, Yoshikawa também criou um indivíduo buscando valores e "o caminho", cujos atalhos são marcados não 
só pelo sucesso, mas também por fracassos e dúvidas; e, nesse sentido [...] Com essa determinação, disciplina e busca por vaIores mais elevados, Musashi enfim transcende a matéria bruta que marca seus primeiros passos e supera até mesmo os obstáculos mais formidáveis. (WILSON, 2006, p. 226)

Como Wilson aponta, nem todas as experiências de Musashi são necessariamente constituídas de sucesso. Desta maneira, a presença de fracassos e dúvidas na trajetória do protagonista evidencia a sua humanidade.

Talvez o episódio mais importante que contribui para a mudança da personalidade de Musashi ocorra quando ele é confrontado por Takuan e depois permanece trancafiado até que alcance a erudição pelas letras.

A "capacidade de se aperfeiçoar" está reservada apenas ao estado da cultura, ao homem civilizado. Ao mesmo tempo, é também no estado da civilização que ocorre a corrupção. (MAAS, 2000, p. 67-8)

Até então Musashi, ou melhor, Takezō, era descrito como um indivíduo animalizado, cometendo equívocos atrás de equívocos. Mas após transformar-se, está apto a conduzir-se rumo a seu autodesenvolvimento. Mesmo que este não seja o foco deste trabalho, podemos cogitar que esta desvirtuação ocorre em seu antagonista, Sasaki Kojirō.

Outro talento explorado por Musashi, de maneira autodidata, é sua caligrafia. Em nenhum momento vimos quando surge esta recreação, porém a troca de cartaz e a fixação de placas são bastante recorrentes na obra. Assim, sua aptidão acompanha o desenvolvimento como espadachim. "- A caligrafia é elegante. / - É um homem incomum - murmuravam." (YOSHIKAWA, 2004, p. 312). A partir da sua caligrafia, notáveis guerreiros conseguiam reconhecer as qualidades atípicas que Musashi possuía. 
Cuidadoso exame do cartaz revela, porém, que os ideogramas, aparentemente do próprio punho do mestre, deixam muito a desejar como modelo caligráfico. Um ou outro especialista talvez lance um olhar de esguelha e sorria desdenhoso ao passar por ali. Mestre Muka, porém, não considera sua obra vergonhosa. E quando alguém se dá ao trabalho de questionar, dizem que responde: "Paciência! Eu também sou criança e estou aprendendo." (YOSHIKAWA, 2004, p. 1641)

Por um determinado momento de reclusão, Musashi adota 0 pseudônimo Muka e atua como professor de leitura e escrita. Mas com um tom jocoso, declara que mesmo sendo um mestre, está - sempre em desenvolvimento.

Articulada à caligrafia e possivelmente sendo o que originou esta habilidade, a pintura também tem uma significativa presença. No romance, há o relato de que Musashi sempre gostou de desenhar durante a sua infância, mas interrompeu esta prática por passar por um momento sombrio na adolescência, só retornando a estimular-se a desenhar quando entrou em contato com várias obras enquanto realizava sua jornada de aprendizado.

"Ah! Não é nada fácil pintar!", deu-se conta Musashi de repente, fascinado com o trabalho do artista, encontrando um lenitivo para o próprio tédio.

"No momento em que, com o oponente posicionado além da ponta da espada, perco a noção de mim mesmo, quando sinto que o universo e eu perfazemos uma unidade, ou melhor, quando perco a própria noção de sentir alguma coisa, nesse exato instante minha espada terá golpeado o inimigo certeiramente. O senhor Koetsu não consegue desenhar o riacho de modo satisfatório porque ainda contempla a água como um inimigo. Ele próprio tem de ser a água", raciocinou Musashi. Longe da esgrima, nada existia para ele. 
Compreendia vagamente as dificuldades da pintura ao comparálas com as da esgrima. (YOSHIKAWA, 2004, p. 645)

Este trecho é relevante para poder ilustrar uma das qualidades de Musashi apontada por Wilson (2006, p. 219), o entendimento. O protagonista consegue transpor as habilidades de Hon'ami Kōetsu, do plano da pintura para a esgrima. Enxerga as brechas do idoso artista, como também elucida este problema.

Além disso, quando tem sua indicação à casa xogunal negada, o entrevistador faz um pedido surpreendente à Musashi:

- Mudando de assunto, ouvi dizer que você tem educação refinada, incomum em rudes guerreiros. Qualquer que seja ela, gostaria de apresentá-la ao xogum. Não tem por que se incomodar com os ataques e as maledicências da plebe, mas nesta oportunidade quero que você ultrapasse a barreira dos rumores populares e expresse a sua convicção, sua verdade interior, por intermédio da arte que melhor domina. Considero que esta será a sua resposta, a resposta de um bushi de alta formação. (YOSHIKAWA, 2004, p. 1525)

A excepcional habilidade do protagonista em desenhar foi utilizada para traduzir toda a sua natureza. Aqueles que conseguiam decifrar Musashi acreditavam estar na presença de um indivíduo único.

Uma das difamações citada acima, criadas a fim de prejudicar Musashi, fora quando ele liquidara o jovem Genjirō, herdeiro da família Yoshioka, na batalha contra mais de 60 adversários. Assim, deturparam o verdadeiro ocorrido no esforço de arruinar a imagem do protagonista.

E assim, enquanto se recobrava dos ferimentos, ele havia começado a esculpir a imagem da deusa Kannon. O gesto, mais que um ritual em memória do menino morto, era uma prece pela própria alma acabrunhada. (YOSHIKAWA, 2004, p. 938) 
Neste momento, como uma penitência, Musashi é despertado a transmitir a sua perturbação na imagem da deusa Kannon 觀音, Avalokiteshvara bodisatva associada com a misericórdia. Provavelmente é o ofício mais complicado a que o protagonista se dedicou.

Explorado pelo ponto de vista do exílio no capítulo anterior, a temporada que Musashi passou em Hōtengahara foi-Ihe de extrema utilidade para que ele desenvolvesse uma competência até então inexistente. O protagonista, após muitos esforços, consegue, com a ajuda dos habitantes daquela região controlar os danos das enxurradas, tornando produtivo o local que sofria com a miséria. Mas agora, examinando através do romance de formação, Maas (2000, p. 43) explica que o projeto de auto aperfeiçoamento de um indivíduo, em um dado momento, passa a exigir que todas as experiências vividas se conectem entre si e resultem numa competência que possa ser posta em prática, não como propósito particular, mas sim voltada à coletividade. "Musashi retraçou então toda a sua estratégia expansionista: desistiu de tentar dominar a natureza e passou a trabalhar no sentido de servi-la lealmente." (YOSHIKAWA, 2004, p. 1187). Assim como compreendia a dificuldade de Kōetsu em desenhar, pois ele enfrentava a sua própria arte, raciocina que ele deveria ser subordinado à natureza, e não ao contrário. Depois deste episódio, adequou a percepção que tinha da arte em relação à natureza e trazendo-a para a agricultura, consegue orientar os aldeões.

Quando estavam próximos à capital Edo, Musashi e Iori tomam conhecimento de um festival que acontecia no santuário Mitsumine 三峯 26 , e o jovem garoto insiste para que pudessem participar do festival. Durante o tempo em que assistiam a apresentação de música, Musashi teve uma epifania:

${ }^{26}$ Localizado na cidade de Chichibu 秩父 na província de Saitama 埼玉. 
Enquanto ouvia a canção, Musashi contemplava as mãos dos músicos batendo tambores, e de súbito murmurou, esquecido da presença dos demais espectadores:

- É a técnica das duas espadas!

$[\ldots]$

- É isso! - gemeu ele - Duas espadas, duas baquetas! As baquetas são duas, mas o som é um só!

Imóvel e de braços cruzados, ele se deixou ficar contemplando por muito tempo, mas o cenho descontraído indicava que tinha finalmente solucionado um mistério há muito lhe habitando a mente: a lógica por trás do recurso das duas espadas.

O homem nasce com duas mãos, mas ao esgrimir, usa-as como se uma. (YOSHIKAWA, 2004, p. 1424-5)

Mais uma vez, o episódio contra os numerosos membros da academia Yoshioka é evocado na memória de Musashi quando assimila o ato do músico debater nos tambores à sua performance na luta, quando instintivamente arma-se com as duas espadas para confrontar seus adversários. A partir deste momento, começa a decifrar o seu estilo de duas espadas, conhecido como Niten ichiryū 二天一流.

Para que pudesse evoluir na esgrima, Musashi não necessariamente treinava de maneira ininterrupta, e esta marca está bastante presente na obra.

Para aprimorar a esgrima ele praticava o zen, estudava em livros, descontraía-se numa cerimônia de chá, pintava ou esculpia uma imagem santa. Ou podia pegar na enxada. (YOSHIKAWA, 2004, p. 1175)

Foi indispensável entrar em contato e desenvolver-se em outras esferas distintas, para não se esgotar no caminho da autoaprendizagem.

[...] a representação de uma formação universal, por meio da qual todas as habilidades potenciais são cultivadas. [...] um ideal que direciona, educa e harmoniza os talentos, as habilida- 
des e o caráter que cada homem racional já traz em si como patrimônio inato. (MAAS, 2000, p. 45)

Desta forma, segundo Maas, a cada nova experiência Musashi descortina uma habilidade. Entretanto, são descobertas que mantinham-se ocultas até serem estimuladas por meio de uma jornada de conhecimento de si próprio. Além disso, a presença de personalidades instrutivas foi primordial para que o protagonista questionasse sobre a sua própria realização.

\subsection{MESTRE E DISCÍPULO}

Por não seguir pelo caminho tradicional da formação guerreira com a instrução de ensinamentos por meio da relação entre mestre e discípulo -, Musashi é levado a exercer a função de mestre, sem que ele procure efetivamente por isto. Durante o desenvolvimento do romance, há três pessoas e um grupo que podemos considerar sendo aprendizes do protagonista, sendo eles: Jōtarō, Sannosuke Iori, os aldeões de Hōtengahara e Musō Gonnosuke. Este último passa a considerar Musashi como mentor após ser derrotado por ele, mas na obra esta relação não é tão explorada.

Já com Jōtarō e Sannosuke Iori, possivelmente tenha sido a maior demonstração desta capacidade em Musashi. Porém, vale ressaltar que ambos os experimentos não apresentaram o mesmo resultado.

O que mais o preocupava era a própria vida nômade: perguntava-se nesse momento se tinha realmente condições de tornar essa criança feliz, se estava disposto a responsabilizar-se por seu futuro.

Musashi já tivera uma experiência anterior: Joutaro, um menino talentoso. E porque levava uma vida nômade, sempre às voltas com inúmeras situações problemáticas, hoje não sabia sequer por onde andava o garoto. 
"Se Joutaro acabar no mau caminho, a responsabilidade é minha", pensava Musashi com o coração oprimido. (YOSHIKAWA, 2004, p. 1170-1)

Musashi tivera hesitação em acolher ambas as crianças, mas sua provável inexperiência quando conhecera Jōtarō favoreceu com que a execução de um plano de instrução acabasse por fracassar. Desta forma, é possível compreender que este não fora o momento oportuno para o protagonista. Por outro lado, ao relacionar-se com Iori, Musashi já havia vivenciado alguns anos da sua trajetória e seu discernimento não era mais o mesmo.

[...] esse tipo de preocupação inibe qualquer tipo de iniciativa. Ninguém é capaz de prever o que poderá acontecer a si próprio dentro de alguns minutos, quanto mais de garantir que uma criança - um ser cuja vida mal começou - será feliz ou não num remoto futuro. Pouco razoável era também planejar o futuro de uma pessoa dotada, como todas, de vontade própria. (YOSHIKAWA, 2004, p. 1171)

Esta preocupação que afligia o protagonista era pela experiência falha com Jōtarō, receoso em repetir o mesmo com Iori. Mas ele observa neste momento uma oportunidade de instruir alguém; ao mesmo tempo em que realizaria um auto aprendizado, avalia que não deveria hesitar frente à imprevisibilidade da vida.

[...] na iminência de desempenhar o papel de educador de um espírito mais jovem e supostamente mais despreparado do que o seu, [...] tem chance de refletir sobre sua própria condição, sobre o estágio de sua própria formação. (MAAS, 2000, p. 155)

De acordo com Maas, o indivíduo, ao vir a ter condição de servir como instrutor a outra pessoa - que se mostra inexperiente -, pode realizar um estudo profundo sobre sua própria trajetória e determinar ao 
seu discípulo as melhores direções no aperfeiçoamento pessoal. Musashi, discernindo que não havia necessidade em uma criança praticar a esgrima com tanto afinco neste estágio da vida, pondera que deveria existir uma divisão de ocupações, além da necessidade de aproveitar a infância. Com isto, o protagonista determina que Iori exerça quatro funções: o trabalho no campo, o aprendizado da esgrima, a dedicação à leitura e a simples diversão para uma criança.

Joutaro não tinha sido educado desse modo porque Musashi acreditara, à época, que uma criança devia ter a liberdade de agir como bem entendesse, e que essa seria a maneira correta de promover o crescimento natural de um ser. Ele próprio fora criado assim.

Com o passar dos anos, porém, seu modo de pensar alterou-se. O homem tinha tendências naturais que precisavam ser estimuladas e outras que, ao contrário, deviam ser inibidas. Deixadas à vontade, certas qualidades indesejáveis vicejavam, enquanto outras, positivas, estagnavam.

Era uma realidade, que constatava até com relação às plantas que cortara para construir a choupana: árvores que gostaria de ver brotando uma vez mais desapareciam para sempre, enquanto arbustos inúteis e ervas daninhas tornavam a medrar por mais que os ceifasse. (YOSHIKAWA, 2004, p. 1359)

Possivelmente por não ter tido este cuidado em educar o jovem Jōtarō, o protagonista sentiu-se arrependido por não ter exercido sua função de mestre. Com esta nova oportunidade, esforça-se para dar a melhor criação que poderia oferecer a Iori. Com isto Musashi consegue, por meio da formação, moldar uma base essencial para alavancar Iori a tornar-se um protegido de Nagaoka Sado, um samurai de extrema importância do clã Hosokawa.

Por fim, outra etapa importante no aperfeiçoamento do próprio protagonista foi a empreitada realizada na campina de Hōtengahara. Começa a trabalhar sozinho com Iori, para domar a força da natureza 
nos períodos de enchente e transformar terras improdutivas em cultiváveis. Inicialmente sofre uma desconfiança por parte dos aldeões, mas quando eles enxergam o valor que Musashi possuía, passam a auxiliá-lo.

\footnotetext{
"Quem quiser me ajudar, pode vir. Quem sonha com uma vida melhor, também. Prover apenas o próprio sustento e morrer é o destino de pássaros e animais selvagens. Mas quem almeja deixar o fruto do seu trabalho como herança para filhos e netos deve vir aqui e me ajudar", teria ele dito.

$[\ldots]$

- Tudo isso foi o resultado do seu trabalho, não meu. Eu apenas mostrei-Ihes como externar a força que existia em vocês. (YOSHIKAWA, 2004, p. 1215)
}

Ao interpelar os aldeões, Musashi estimula-os para que se esforcem nesta atividade, acreditando que o trabalho em equipe proporcionaria ótimos ganhos para um povo tão desacreditado, e com sua modéstia, manifesta que o sucesso foi resultado do empenho de cada um deles. Assim, o papel do mestre de lapidar seus discípulos foi imprescindível para revelar a virtude do povo de Hōtengahara. "A tarefa de trabalhar a água e o solo e produzir uma área fértil e habitável, era no seu entender o mesmo que trabalhar o homem, governar um país e conduzi-lo para o progresso." (YOSHIKAWA, 2004, p. 1177). Todo este empenho aplicado por Musashi nada mais foi que um processo de auto avaliação para compreender em que nível estava a sua formação, já que comandar os trabalhos de uma vila demandava uma certa perícia.

\subsection{APÓS O ÚLTIMO EMBATE}

Nos momentos finais do romance, após Musashi haver derrotado Sasaki Kojirō, o narrador realiza uma breve avaliação sobre o nível que o protagonista havia alcançado em toda a sua trajetória. 
Mas o que o fizera vencer um inimigo superior? Técnica? Ajuda divina?

Era fácil negar, mas, a bem da verdade, Musashi não sabia.

De um modo vago, era algo que superava a força ou ajuda dos céus. Kojiro tinha acreditado na esgrima voltada para a técnica e a força, enquanto Musashi acreditara na esgrima espiritual. Essa era a única diferença. (YOSHIKAWA, 2004, p. 1807)

O próprio protagonista não compreendia como havia vencido a batalha, mas o narrador atribui a vitória de Musashi a uma "esgrima espiritual". Isto pode ser interpretado como a junção das múltiplas experiências obtidas em diferentes domínios e canalizadas de maneira sublime. [...] o protagonista dos Bildungsromane alcança, segundo as definições tradicionais do gênero, um equilíbrio no fim de sua trajetória, um misto de "harmonia com liberdade" [...] (MAAS, 2000, p. 72, grifo do autor). De acordo com Maas, o herói do romance de formação, ao final da obra, alcança uma mistura harmônica das experiências vividas com a liberdade de que usufruiu ao longo do seu caminho, por obstinarse a desenvolver algo além do que Ihe era destinado. Assim, Musashi apresenta uma harmonia de todas as formas de aprendizado que teve oportunidade de vivenciar. A liberdade que emana do seu ser, malvista por muitos que não o compreendiam, fora um fator determinante para que ele pudesse desenvolver-se de maneira inusitada.

Para finalizar o romance, o narrador incumbe o leitor a decidir quais seriam os próximos passos de Musashi:

No momento seguinte, Musashi corria rumo ao lado norte da praia e saltava agilmente para dentro do bote que o aguardava, ainda empunhando o remo imaculadamente limpo: nem uma única gota de sangue o sujava.

Que direção tomou o bote, onde teria ele aportado? (YOSHIKAWA, 2004, p. 1808) 
Tal como o narrador retira-se, ele demonstra que Musashi não tinha interesse em gozar da vitória recém-conquistada, que poderia ser bastante vantajosa. [...] não se associa efetivamente a uma classe social. Renegando os limites impostos por sua origem, [...] também não ascende à aristocracia, permanecendo, portanto, em uma espécie de limbo social. (MAAS, 2000, p. 152). Segundo Maas, o indivíduo, ao final da obra, passa a situar-se em uma zona indefinida. Sem consentir com as limitações com que sua classe vive, também não tem oportunidade de ascender à camada superior, da qual utilizou-se para desenvolver-se. Ao que tudo indica, na trajetória de Musashi, ele acredita que tornar-se um samurai colocaria em risco sua liberdade, e sua auto formação, assim como o progresso no caminho da espada, que chegaria ao fim. 


\section{CONSIDERAÇÕES FINAIS}

Este trabalho não pretende tecer conclusões sobre a trajetória de Miyamoto Musashi narrada por Yoshikawa Eiji, uma vez que este excepcional personagem não crê que tenha alcançado grandes progressos em sua vida, compreendendo que o auto desenvolvimento é um ato contínuo e interminável.

Como Henshall (2008, p. 81) explica, o Japão do início do século XVII passou por grandes convulsões até dar início a quase 300 anos de uma aparente paz. O xogum Tokugawa Ieyasu e seus sucessores acreditavam que a estabilidade e a rigidez impostas eram importantes para a manutenção do seu domínio. Assim, uma das maiores ameaças a este sistema era a mobilidade. Para extinguir esta prática, foi indispensável impor modos determinados e prescritos a fim de limitar o povo. Consequentemente, estabilizou-se uma estratificação social que dificultava a ascensão daqueles que almejavam uma condição superior.

Musashi, com sua determinação, consegue romper estas amarras da sociedade, perseguindo as ambições particulares. Não se sentia confortável em constituir parte da coletividade, pois sua individualidade era, em partes, incompreendida.

Esta incompreensão levou-o a ser exilado, mas a solução encontrada por Musashi foi fomentar sua criatividade nesta condição. Como o próprio Katō evidencia, "Juntamente com a natureza, eles encontraram "o caminho que deveriam seguir fielmente", ou seja, a criatividade para uma nova arte." (2012, p. 263). Portanto, o exílio que Musashi vivencia não é exclusivamente caracterizado por ruptura, rejeição e renúncia, mas o que Yoshikawa exalta em seu romance é: sutura, reconstrução e criação (QUEIROZ, 1998). Em conjunto com estas características, Said (2003) expõe a existência de possibilidades prazerosas durante esta vida solitária, ao "aceitar o mundo inteiro como uma terra estrangeira", 
amplificando seu ponto de vista, posto que o exilado não se sente satisfeito com seu desenvolvimento.

Neste caso, as características de Musashi como um romance de formação assemelham-se ao conceito exposto por Maas (2000), apresentando a trajetória de um jovem protagonista. Inicialmente é atormentado por convicções errôneas e julgamentos falhos, mas após ser instruído de maneira adequada, percorre uma trajetória tomada por experiências que irão the moldando, até chegarmos a um "efetivo aperfeiçoamento do protagonista", expondo um equilíbrio entre harmonia e liberdade. 


\section{REFERÊNCIAS BIBLIOGRÁFICAS}

BAKHTIN, Mikhail. O romance de educação na história do realismo. In: Estética da criação verbal. Trad.: Maria Ermantina Pereira. São Paulo: Martins Fontes, 2011. p.205-258.

Questões de Literatura e de Estética, a Teoria do Romance. Tradução: Aurora Fornoni Bernardini. 4.ed. São Paulo: UNESP/Hucitec, 1988.

GORDON, Andrew. A Modern History of Japan: From Tokugawa Times to the Present. New York: Oxford University Press, 2003.

HENSHALL, Kenneth. História do Japão. Tradução: Victor Silva. Lisboa: Edições 70, 2008.

HISSA, Cássio E. V. A Mobilidade das Fronteiras. Belo Horizonte: Editora UFMG, 2002.

INOUE, Takehiko. Vagabond Illustration Collection: Sumi. São Francisco: Viz Media, 2008.

KAPLEAU, Philip. The Three Pillars of Zen. New York: Beacon Press, 1967. 
KARATANI, Kojin. Origins of Modern Japanese Literature. Durham: Duke University Press, 1993.

KATO, Shūichi. A History of Japanese Literature: The Modern Years. Translation: Don Sanderson. Tokyo: Kodansha International, 1983.

Tempo e Espaço na Cultura Japonesa. Tradução: Neide Nagae e Fernando Chamas. São Paulo: Estação Liberdade, 2012.

KEENE, Donald. Dawn to the West: Japanese Literature in the Modern Era, Fiction. New York: Owl Book, 1987.

. Dawn to the West: Japanese Literature in the Modern Era, Poetry, Drama, Criticism. New York: Owl Book, 1987.

KOBAYASHI, Luiz. Peregrinos do Sol: A Arte da Espada Samurai. São Paulo: Estação Liberdade, 2010.

MAAS, Wilma P. M. D. O Cânone Mínimo: O Bildungsroman na História da Literatura. São Paulo: Editora UNESP, 2000.

MILLER, J. Scott. Historical Dictionary of Modern Japanese Literature and Theather. Maryland: Scarecrow Press, 2009. 
MIYAMOTO, Musashi. O Livro dos Cinco Anéis. Trad.: Dirce Miyamura. São Paulo: Conrad Editora do Brasil, 2006.

NAKAMURA, Mitsuo. Contemporary Japanese Fiction, 1926-1969. Tokyo: Kokusai Bunka Shinkokai, 1969.

OZAKI, Hideki. Yoshikawa Eiji - hito to bungaku (Eiji Yoshikawa pessoa e literatura). Tokyo: Shin'yūdō, 1980.

QUEIROZ, Maria José de. Os males da ausência, ou A literatura do exílio. Rio de Janeiro: Topbooks, 1998.

REUTER, Yves. Introdução à análise do romance. 2.ed. São Paulo: Martins Fontes, 2004.

RICHIE, Donald. Japanese Literature Reviewed. New York: ICG Muse, 2003.

SAID, Edward W. Orientalismo: O oriente como invenção do Ocidente. Tradução: Rosaura Eichenberg. São Paulo: Companhia das Letras, 2007.

Reflexões Sobre o Exílio e Outros Ensaios. Tradução:

Pedro Maia Soares. São Paulo: Companhia das Letras, 2003. 
SAKURAI, Célia. Os Japoneses. São Paulo: Contexto, 2007.

STORRY, Richard. A History of Modern Japan. Baltimore: Penguin Books, 1963.

TIHANOV, Galin. Narrativas do Exílio: Cosmopolitismo Além da Imaginação Liberal. São Carlos: Pedro \& João Editores, 2013.

TOKITSU, Kenji. Miyamoto Musashi: His life and writings. Translation: Sherab Chodzin Kohn. Boston: Shambhala, 2004.

VOLOBUEF, Karin. Frestas e arestas: a prosa de ficção do romantismo na Alemanha e no Brasil. São Paulo: Fundação Editora da UNESP (FEU), 1999.

WILSON, William Scott. O Samurai: A vida de Miyamoto Musashi. Tradução: Mauro Pinheiro. São Paulo: Estação Liberdade, 2006.

YAMASHIRO, José. História da Cultura Japonesa. São Paulo: Ibrasa, 1986.

História dos Samurais. São Paulo: Ibrasa, 1993. 
YAMAGIWA, Joseph K. Japanese Literature of the Shōwa Period: A Guide to Japanese Reference and Research Materials. Ann Arbor: The University of Michigan Press, 1959.

YOSHIKAWA, Eiji. Musashi, volume I. Tradução: Leiko Gotoda. 10.ed. São Paulo: Estação Liberdade,2004.

. Musashi, volume II. Tradução: Leiko Gotoda. 8.ed. São Paulo: Estação Liberdade, 2004.

\section{DOCUMENTOS ELETRÔNICOS}

BRASIL, Ubiratan. 0 eterno sucesso das aventuras do samurai Musashi. São Paulo: O Estado de São Paulo. Disponível em: < http://cultura.estadao.com.br/noticias/artes,o-eterno-sucesso-dasaventuras-do-samurai-musashi,295652> Acesso em: 16 nov. 2016.

SHIMADA MUSEUM. Kumamoto: Museu Shimada. Disponível em: <http://www.shimada-museum.net/musashi.html> Acesso em: 29 dez. 2017.

YAHOO BLOGS. Japão. Disponível em: <https://blogs.yahoo.co.jp/sw21akira/44441695.html> Acesso em: 29 dez. 2017. 
KODANSHA. Japão. Disponível em:

<http://www.kodansha.co.jp/about/nextgeneration/award/25036.html

$>$ Acesso em: 29 dez. 2017.

KODANSHA BOOKCLUB. Japão. Disponível em:

<http://bookclub.kodansha.co.jp> Acesso em: 29 dez. 2017.

ESTAÇÃO LIBERDADE. São Paulo: Editora Estação Liberdade. Disponível em: < http://www.estacaoliberdade.com.br> Acesso em: 29 dez. 2017. 